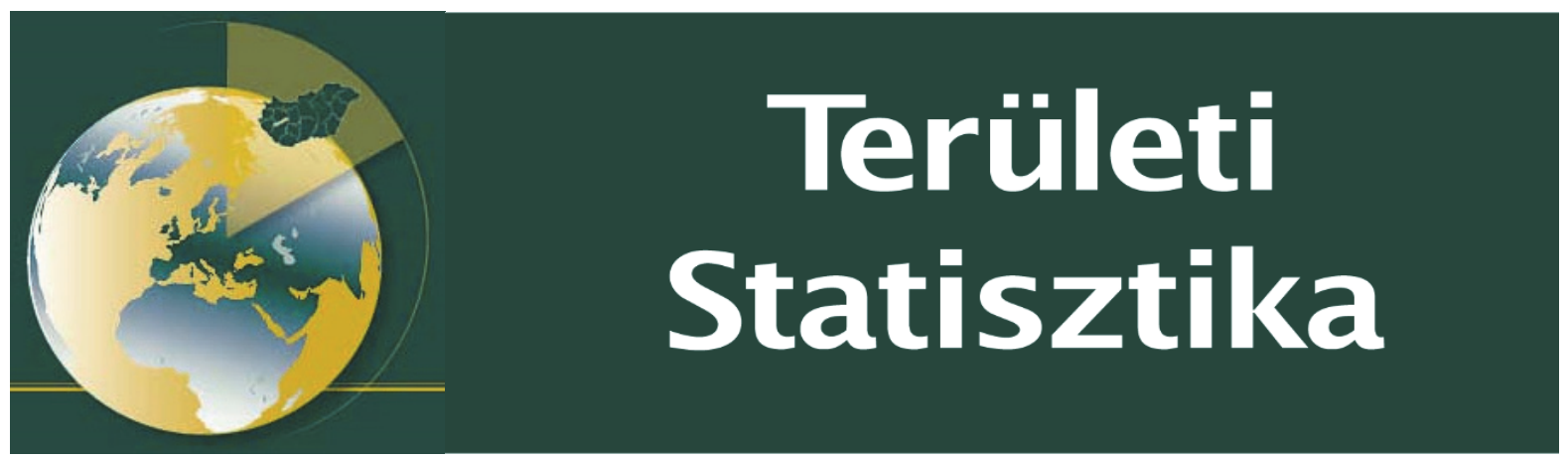

Közzététel: 2018. december 19.

A tanulmány címe: Szerzők:

Vidéki nagyvárosaink gazdaságának összehasonlító elemzése

Molnár Ernő Debreceni Egyetem Társadalomföldrajzi és'Területfejlesztési Tanszék,

E-mail: molnar.erno@science.unideb.hu

Dézsi Gyula EDC Debrecen Város- és Gazdaságfejlesztési Központ,

E-mail: dezsi.gyula1902@gmail.com

Lengyel István Máté EDC Debrecen Város- és Gazdaságfejlesztési Központ,

E-mail: pityihun@hotmail.com

Kozma Gábor Debreceni Egyetem Társadalomföldrajzi és'Területfejlesztési Tanszék,

E-mail: kozma.gabor@science.unideb.hu

https://doi.org/10.15196/TS580604

Az alábbi feltételek érvényesek minden, a Központi Statisztikai Hivatal (a továbbiakban: KSH) Területi Statisztika c. folyóiratában (a továbbiakban: Folyóirat) megjelenó tanulmányra. Felhasználó a tanulmány, vagy annak részei felhasználásával egyidejüleg tudomásul veszi a jelen dokumentumban foglalt felhasználási feltételeket, és azokat magára nézve kötelezönek fogadja el. Tudomásul veszi, hogy a jelen feltételek megszegéséből eredö valamennyi kárért felelösséggel tartozik.

1) A jogszabályi tartalom kivételével a tanulmányok a szerzői jogról szóló 1999. évi LXXVI. törvény (Szjt.) szerint szerzői műnek minősülnek. A szerzői jog jogosultja a KSH.

2) A KSH földrajzi és időbeli korlátozás nélküli, nem kizárólagos, nem átadható, térítésmentes felhasználási jogot biztosít a Felhasználó részére a tanulmány vonatkozásában. 3) A felhasználási jog keretében a Felhasználó jogosult a tanulmány:

a) oktatási és kutatási célú felhasználására (nyilvánosságra hozatalára és továbbítására a 4. pontban foglalt kivétellel) a Folyóirat és a szerző(k) feltüntetésével;

b) tartalmáról összefoglaló készítésére az írott és az elektronikus médiában a Folyóirat és a szerző(k) feltüntetésével;

c) részletének idézésére - az átvevő mű jellege és célja által indokolt terjedelemben és az eredetihez híven - a forrás, valamint az ott megjelölt szerző $(\mathrm{k})$ megnevezésével.

4) A Felhasználó nem jogosult a tanulmány továbbértékesítésére, haszonszerzési célú felhasználására. Ez a korlátozás nem érinti a tanulmány felhasználásával előállított, de az Szjt. szerint önálló szerzői műnek minősülő mű ilyen célú felhasználását.

5) A tanulmány átdolgozása, újra publikálása tilos.

6) A 3. a)-c.) pontban foglaltak alapján a Folyóiratot és a szerző(ke)t az alábbiak szerint kell feltüntetni:

„Forrás: Területi Statisztika c. folyóirat 58. évfolyam 6. számában megjelent, Molnár Ernő - Dézsi Gyula - Lengyel István Máté -Kozma Gábor által irt Vidéki nagyvárosaink gazdaságának összehasonlitó elemzése c. tanulmány"

7) A Folyóiratban megjelenő tanulmányok kutatói véleményeket tükröznek, amelyek nem esnek szükségképpen egybe a $\mathrm{KSH}$, vagy a szerzők által képviselt intézmények hivatalos álláspontjával. 


\section{Vidéki nagyvárosaink gazdaságának összehasonlító elemzése}

\section{A Comparative Analysis of the Hungarian Minor Cities}

Molnár Ernő

Debreceni Egyetem

Társadalomföldrajzi és

Területfejlesztési Tanszék

E-mail:

molnar.erno@science.unideb.hu

Dézsi Gyula

EDC Debrecen Város- és

Gazdaságfejlesztési Központ

E-mail:

dezsi.gyula1902@gmail.com

\section{Lengyel István Máté}

EDC Debrecen Város- és

Gazdaságfejlesztési Központ

E-mail:

pityihun@hotmail.com

Kozma Gábor

Debreceni Egyetem

Társadalomföldrajzi és

Területfejlesztési Tanszék

E-mail:

kozma.gabor@science.unideb.hu

Kulcsszavak: nagyvárosok, gazdasági dinamika és szerkezet, növekedési pólus, duális gazdaság
A közepes méretű városok kutatására - a téma fejlesztéspolitikai összefüggései miatt is - jelentős figyelmet fordít korunk Európája. Különösen érdekes a potenciális növekedési pólusoknak tekintett vidéki nagyvárosok gazdasági dinamikájának és szerkezetének vizsgálata Magyarország egyközpontú, főváros-vidék dichotómia által meghatározott térszerkezetében. Tanulmányunk a kérdéshez kapcsolódó magyarországi szakirodalom áttekintése után a települési gazdasági erő becsült nagyságát és a kettős könyvvitelt vezető társas vállalkozások helyi szinten összesített mutatóit elemzi. Továbbá a vizsgált városokban regisztrált nagy-, közép- és potenciális középvállalatok ágazati jellemzőit is tartalmazó adatai alapján az ezredforduló utáni másfél évtized fejlődésének főbb tendenciáit, illetve a hazai nagyvárosok egymáshoz viszonyított pozícióját vizsgálja. Fontos megállapítás, hogy a gazdasági sikerek hátterében elsősorban a külföldi nagyvállalatok által vezérelt, globális termelési hálózatokba történő integrálódás és az újraiparosodás folyamata figyelhető meg. Ehhez ugyanakkor számos potenciális veszélyforrás (egyoldalú függőség, helyi hozzáadott érték korlátozottsága) társul. Magyarország gazdaságának dualitása a vizsgált nagyvárosok teljesítményében is megmutatkozik, elsősorban a fővároshoz közelebb fekvő, lokalizációs előnyökből és kölcsönzött méretből egyaránt profitáló nagyvárosokat kedvező helyzetbe hozva. 

economic dynamics and

structure, growth pole, dual economy

The research of minor cities - also due to the development policy context of the topic - draws significant attention to the contemporary Europe. Examination of the economic dynamics and structure of minor cities regarded as potential growth poles is particularly important in the monocentric space structure of Hungary determined by the dichotomy of Budapest and the rural regions. Our study, after an overview of the relevant Hungarian literature, analyses the estimated economic strength (gross domestic product) of settlements and some locally aggregated economic performance indices of companies using the double-entry bookkeeping system. It also examines the economic development tendencies and the changing relative position of the Hungarian minor cities after the turn of the Millennium, based on data of large, medium-sized and potential medium-sized enterprises registered in these cities. A major result of the paper is that the integration into the global production networks led by big foreign companies as well as the re-industrialization process can be primarily observed in the background of the economic success, which is also associated with some potential threats (like one-sided dependency or limits of local value added). The economic duality of Hungary is well reflected in the performance differences of minor cities, showing the advantageous position of centres located closer to the capital, benefiting from both localization economies and borrowed size.

Beküldve: 2018. szeptember 10.

Elfogadva: 2018. november 3.

Területi Statisztika, 2018, 58(6): 610-637; DOI: 10.15196/TS580604 


\section{Bevezetés}

Ma már közhelynek számít az a megállapítás, mely szerint a globalizáció gazdaságának térszerkezetében felértékelődnek a nagyobb hozzáadott értéket képviselő tevékenységeket, illetve irányító funkciókat koncentráló nagyvárosok (Enyedi 2000). Európa nagyvárosaiban jelentősek az eltérések népességszám, globális városhierarchiában elfoglalt pozíció, gazdasági szerkezet és jövedelmi viszonyok tekintetében. Fejlettségük alapján azonban kiemelkednek környezetükből. Nagyobb termelékenység és foglalkoztatás, magasabb szintủ iskolázottság és innovációs teljesítmény jellemzi őket, amit alapvetóen az agglomerációs gazdaságosságból adódó előnyeikkel magyaráznak (ESPON 2013, EC 2016). Kelet-Közép-Európában a nagyobb fơvárosok mondhatók a globális városhierarchia részének (Taylor-Hoyler-SánchezMoral 2013), a városok második szintje - Lengyelország kivételével - kevésbé fejlett, többnyire 100-300 ezer lakosú, a globalizáció korában kritikus tömegproblémákkal küzdő szereplőkboól áll. A vizsgálatok a foovárosok és a második vonalbeli városok közti termelékenység- és jövedelemkülönbségeket nagyobbnak látják az európai átlagnál, a vidéki nagyvárosok teljesítményének növelését pedig stratégiai jelentőségűnek tartják a nemzetgazdaságok szempontjából (EC 2016). Még a környező országokkal összevetve is nagyok a differenciák a magyar városhálózatban, melynek következtében nincs vidéki nagyvárosunk a régió jelentősebb gazdasági csomópontjai között (Csomós 2011, Páthy 2017, Döbrönte 2018).

A gazdasági funkciók nagyvárosi terekbe koncentrálódásának felismerése - melyet metropolizációnak is neveznek (Kukely 2006) - a társadalom és a gazdaság fennálló területi egyenlőtlenségeinek mérséklése célkitűzés külföldön, illetve Magyarországon is, szorosan összekapcsolódva a policentrikus városhálózat erősítésének gondolatával (Ambrus-Kissné-Kólyáné-Malakucziné 2008, Kovács 2017). A megközelítés az 1950-es és az 1960-as évek erős fővárosi dominanciával küzdő Franciaországában vidéki ellenpólusvárosok fejlesztésére alkalmazott növekedési póluselmélet (Faragó-Lux 2014) adaptációs kísérlete keretében a globalizáció korszaka előtt megjelent Magyarországon. A rendszerváltás utáni országos területfejlesztési koncepciók tartalma alapján is a hazai regionális politika egyik fő törekvésének számít. Az elmúlt évtizedekben végbement változását mutatja a világnak az a hangsúlyeltolódás, mely a fơvárosközpontú térszerkezet oldása, az ellenpólusok fejlesztése helyett/mellett inkább a globalizáció nagyvárosokat preferáló terében történő érvényesülés, a gazdasági sikerhez szükséges kritikus tömegek kialakításának, az agglomerációs gazdaságosságból adódó előnyök kiaknázásának igényével indokolja vidéki nagyvárosaink gazdaságfejlesztésének fontosságát (Lux 2013).

Elemzésünk szempontjából fontosnak tartjuk azokat a kritikai megközelítéseket, melyek egyrészt vitatják, hogy a városok abszolút mérete és gazdasági teljesítóképessége között lineáris összefüggés van a 21. század globális urbanizációs környeze-

Területi Statisztika, 2018, 58(6): 610-637; DOI: 10.15196/TS580604 
tében. Másrészt - a klasszikus agglomerációs előnyökön túl - magyarázatokat keresnek egyes városok relatíve kis méret mellett is megmutatkozó gazdasági dinamikájára és magas termelékenységi szintjére (Camagni-Capello-Caragliu 2013). $\mathrm{Az}$ ellentmondás hátterében gazdaságszerkezeti sajátosságok (ágazati struktúra, vállalatméret), helyi környezeti jellemzők (infrastruktúra, városi kormányzás minősége), illetve városhálózati pozícióval összefüggő adottságok (hálózati integráltság, kölcsönzött méret) állnak (Frick-Rodríguez-Pose 2017). A nagyvárosi agglomerációs előnyökön túl, azoknak ellent nem mondó magyarázatok közül kettőt emeltünk ki. Az egyik az urbanizációs és lokalizációs előnyök között különbséget tevő megközelítés. Eszerint a nagyvárosokra jellemző, eltérő jellegű tevékenységek térbeli koncentrációjából eredő, diverzifikációt megtestesítő ún. jacobsi urbanizációs előnyökkel szemben az egy-egy gazdasági ág térbeli tömörüléséhez köthető, specializációból adódó ún. marshalli lokalizációs előnyök közepes és kisméretú városokban is kialakulhatnak (Lux 2017). Az agglomerációs előnyök szerepét újraértelmező másik magyarázat a kölcsönzött méret koncepciója. A kiemelkedô méretú nagyvárosokkal nem rendelkező, de sû́rủ helyi városhálózatot felmutató régiókban jelentős népszerűségnek örvendő elképzelés lényege, hogy a városok földrajzi közelsége és hálózati összekapcsolása ellensúlyozza a kisebb településméretből, agglomerációs előnyök gyengeségéből adódó hátrányokat, pozitívan befolyásolja a települések gazdasági teljesítményét és funkcionális fejlettségét (Meijers-Burger-Hoogerbrugge 2016, Meijers-Burger 2017).

Tanulmányunk e problémafelvetés alapján a legalább 100 ezer fó lakónépességet koncentráló vidéki nagyvárosaink - továbbá a küszöbértéktől éppen elmaradó Székesfehérvár - gazdaságának elemzésével foglalkozik. A gazdasági tevékenységek különböző méretű és szerkezetű tömörüléseként vizsgálja a településeket, cél a potenciálok és a hátterükben lévő struktúrák összehasonlítása az ezredforduló utáni időszakban. Mely nagyvárosok tekinthetók - a többiekkel összehasonlítva - dinamikusnak, illetve jó pozíciójúnak? Milyen gazdasági szerkezet áll az eltérő teljesítmények hátterében? Mennyire támasztható alá a külföldi tőke vezérelte újraiparosodás hazai területi egyenlőtlenségeket meghatározó szerepe (Kiss 1998, Lux 2017, Lengyel-Varga 2018) a nagyvárosok gazdaságának elemzése alapján? Hogyan illeszthetők be vizsgálatunk eredményei az agglomerációs gazdaságosság és kölcsönzött méret szerepérôl folytatott diskurzusba? A téma bőséges nemzetközi és hazai szakirodalommal rendelkezik, e tanulmányban elsősorban a magyarországi (nagy)városok gazdaságához közvetlenül kapcsolódó elemzések áttekintésére vállalkoztunk. Tanulmányunk empirikus része a települési gazdasági erő becslésére, a kettős könyvvitelt vezetô társas vállalkozások települési szinten összesített mutatójának elemzésére, továbbá a vizsgált városokban regisztrált nagy- (legalább 250 fős), közép- (50-249 fős) és potenciális közép- (20-49 fős) vállalatok (ágazati jellemzőket is tartalmazó) adatainak feldolgozására épül. A vállalkozások részletesebb vizsgálatát a nagy- és középvállalatoknak tulajdonított, gazdasági teljesítményt meghatározó szerep,

Területi Statisztika, 2018, 58(6): 610-637; DOI: 10.15196/TS580604 
a potenciális középvállalatok figyelembevételét egy magyarországi vizsgálat (Kovács-Lux-Páger 2017) inspirálta. A felhasznált adatok a Központi Statisztikai Hivatal, a Nemzeti Adó- és Vámhivatal, a Magyar Államkincstár, valamint a Creditreform online céginformációs adatbázisából származtak.

\section{A hazai nagyvárosok gazdasága a szakirodalomban}

A nagyvárosi gazdaságok összehasonlító vizsgálata három témakör metszeteként jelenik meg a hazai földrajzi-regionális tudományi szakirodalomban. Egyrészt, meghatározó szerepet játszik a térbeli társadalmi-gazdasági egyenlőtlenségek települési vagy kistérségi/járási szintű kutatásaiban, mely sokféle indikátorkészlettel, illetve változatos módszertani eszköztárral a fejlettség-fejletlenség (centrumperiféria) dimenziói mentén írja le a különbségeket. Fontos tanulsága ezen elemzéseknek, hogy a nagyvárosok - bár eltérések mutatkoznak dinamikájukban, környezetükre gyakorolt gazdaságélénkító hatásaikban (Tóth-Nagy 2013) - az elmúlt három évtized átalakulásának nyertesei, azaz a területi egyenlőtlenségi dimenziók egyike a településhierarchia mentén határozható meg (Nemes Nagy 1996, Pénzes 2014). Vizsgálatunk középpontjában vidéki nagyvárosaink gazdasági teljesítménye áll. Számunkra módszertani értéke azon balatoni települések fejlettségi viszonyait elemző kutatásnak van, mely a települési GDP regisztrált vállalkozások számán, illetve helyi adóbevételek és adóköteles jövedelmek nagyságán alapuló becslésével kísérli meg a területi egyenlőtlenségeket bemutatni (Lőcsei-Nemes Nagy 2003). Az ún. települési gazdasági erő abszolút értéke nagyvárosaink esetében is alkalmas a gazdasági potenciálok jellemzésére.

A városhálózat differenciálódásának feltárásához az ezredforduló táján teret nyert, fajlagos mutatókra épülő települési versenyképesség-kutatások is hozzájárultak. Egy részük csak a nagyobb (megyei jogú) városok és vonzáskörzeteik összehasonlítására vállalkozott (Lengyel-Rechnitzer 2000, Egedy 2012, Tóth-Nagy 2013), mások a teljes magyarországi városhálózatra kiterjesztették vizsgálataikat (Nemes Nagy 2004) vagy területi alapon szúkítették az elemzést, és a településállomány egészéről közöltek információkat (Pénzes 2015). Az alkalmazott mutatóktól, módszerektől és időintervallum hosszától függően a különböző települések eltérô pozíciója figyelhetô meg, versenyképesség szerinti differenciálódásukban ugyanakkor területi és hierarchikus hatások is érvényesülnek. Versenyképes települések nagyobb arányban fordulnak elő az ország sikeresebb központi és északnyugati térségeiben, valamint a városhierarchia magasabb szintjein. Alátámasztja e megállapítást az alföldi települések között található kevés versenyelônyös szereplő, az ország keleti részén a jobb versenyképességi mutatók nagyvárosokra és szuburbán településekre korlátozódása (Pénzes 2015), valamint az elmaradott térségekre jellemző versenyelőnyös központ-versenyhátrányos vonzáskörzet párosítás (Tóth-Nagy 2013).

Területi Statisztika, 2018, 58(6): 610-637; DOI: 10.15196/TS580604 
A városhálózat differenciálódásának sajátos megközelítését képviselik a települések innovációorientáltságát érintő vizsgálatok. Az ezredforduló után, abszolút arányt és relatív fejlettséget egyaránt megjelenítő gazdasági és társadalmi mutatókra támaszkodó, évtizedes különbséggel megismételt faktor- és klaszterelemzések a városhálózat stabilitását jelzik. Mintegy 50-60 megújulásra képes nagy-, közép- és kisvárost azonosítottak, melyek közül Budapest után négy komplex szerkezetű, erős innovációs potenciállal, képzett munkaerővel, de korlátozott gazdasági súllyal rendelkező regionális központ (Debrecen, Pécs, Szeged, Miskolc), illetve három erősebb gazdasági bázisú, de humánerőforrás- és innovativitási mutatóiban gyengébb település (Győr, Székesfehérvár, Kecskemét) emelkedett ki (Rechnitzer-CsizmadiaGrosz 2004, Rechnitzer-Páthy-Berkes 2014).

A releváns kutatások második, témánkhoz szorosan kapcsolódó csoportját a települések gazdaságára fókuszáló vizsgálatok adják. Fontos vonatkoztatási pont a hazai városhierarchia hosszabb távú fejlődését leltározó módszerrel, a városok lényegét adó központi funkciók mennyiségi és minőségi jellemzőinek számbavételével történő elemzés, ami - különösen magasabb szinteken - a magyarországi városhálózat viszonylagos stabilitását mutatja a 20. században. Budapestet követô regionális központok száma négyről ötre bővült. Debrecen, Szeged, Pécs és Győr mellett Miskolc is a vidéki elit tagjává vált, a többi nagyvárosunk egy szinttel alacsonyabban, a megyeközpont kategóriában található a 20. század elején és végén egyaránt (Beluszky-Győri 2004). A szimpla gazdasági összehasonlító elemzésen túlmutató vizsgálatot a központi funkciók jelentős részének szolgáltatási tevékenységek formájában történő megjelenése teszi elemzésünk szempontjából érdekessé.

Tanulmányunk tematikájához legközelebb a városok abszolút gazdasági erejét kifejező gazdasági potenciálok összevetésére törekvő tanulmányok állnak. Nagy Erika és Nagy Gábor statikus vizsgálata a kettős könyvelést végzô vállalatok 2005. évi adataira épült. Figyelembe vették az árbevétel nagyságát (gazdasági erô), a bruttó hozzáadott érték relatív nagyságát (értékteremtő képesség), az export értékesítés jelentőségét és a külföldi tőke arányát a jegyzett tôkéből (külpiaci aktivitás, globalizáció folyamatába integrálódás). Vizsgálatuk kiegészült egyéb - a helyi gazdaság kisebb vállalkozásokhoz és intézményi foglalkoztatáshoz kötődő szegmenseinek bemutatására is alkalmas - mutatókkal, melyek egyrészt oldják a tisztán vállalati adatokra épülő elemzés egyoldalúságát, másrészt nehezen reprodukálhatóvá teszik a munkát egy olyan vizsgálat számára, mely több év állapotának összehasonlítását célozza. Utóbbiak a nem helyi munkavállalóknak nyújtott munkahelyek számát (foglalkoztatási szerep), az üzleti szolgáltatók abszolút számát és diverzifikáltságát, valamint a bolthálózat fejlettségét, a külföldi és hazai kereskedelmi láncok helyi megjelenését (fogyasztásiközpont-szerep) elemzik. A gazdasági központok hierarchiája Budapest után a külföldi múködő tőke vonzásában élenjáró Győr és Székesfehérvár kiemelkedő pozícióját, valamint a többi vidéki nagyváros második vonalba sorolását mutatja.

Területi Statisztika, 2018, 58(6): 610-637; DOI: 10.15196/TS580604 
Figyelemre méltó Szombathely első vonalba kerülése, valamint - a vizsgált nagyvárosok között - Nyíregyháza gyenge pozíciója (Nagy E.-Nagy G. 2008).

Hasonló a helyi székhelyú cégek pénzügyi adatai alapján számolt településgazdasági súly (továbbiakban TGS) mutató is (Csomós 2013, 2015). Előállitásához a Forbes magazin vállalatok rangsorolására használt, de globális gazdaságirányító és ellenőrző központjainak kutatásában is alkalmazott mérőszámaira (forgalom, piaci érték, eszközállomány, profit) hasonlító hazai - települési szintú - indikátorokat használta fel, melyeket a szerző a kettős könyvvitelt vezető vállalatok adataiból gyújtött le. A TGS 1990-es és 2000-es évekre kiszámolt értékei - a hazai összesített TGS megközelítőleg 50\%-át adó Budapest után - a vidéki nagyvárosok és néhány ipari központ kiemelkedő szerepét mutatták. Változott azonban az egyes nagyvárosok egymáshoz viszonyított pozíciója. A lista elején Győrt csak átmenetileg előzte meg Székesfehérvár az ezredfordulón, de az utolsó helyen álló nagyváros - az 1990-es évek elején Kecskemét (országos 15. helyezés), az ezredfordulón Nyíregyháza (14.), egy évtizeddel később pedig Pécs (13.) - többször változott. A mindenkori leggyengébb nagyváros egy-egy hellyel történő előrelépése jelzi, hogy egyre nehezebb kisebb, azaz nem nagyváros településeknek a lista elejére kerülni. Kiszorultak az 1990-es évek elején még kedvező pozícióban lévő iparvárosok (Paks, Dunaújváros, Tiszaújváros), és megjelent néhány új ipari központ (Komárom, Jászfényszaru), a Budapesti agglomeráció egy-egy kitüntetett települése (Budaörs) vagy offshore telephely (Újlengyel). Ezek területi elhelyezkedése inkább a nagyvárosi térségek felértékelődését bizonyítja. Az ezredforduló idejére hasonló eredményeket produkáló gazdasági potenciál- és TGS-vizsgálatokból adaptáltuk elemzésünkbe a kettős könyvvitelt vezető társas vállalkozások néhány, évenként is rendelkezésre álló adatát (bruttó hozzáadott érték, kibocsátás, értékesítés nettó árbevétele, exportárbevétel, foglalkoztatottak átlagos statisztikai állományi létszáma).

Vizsgálatunk gazdasági szerkezetet érintő aspektusaként, a különböző gazdasági tevékenységeket nagyvárosi terekben vagy hazai településhálózatban vizsgáló elemzések emelhetők ki a releváns irodalom harmadik csoportjaként. Az összehasonlító jellegú munkák többsége - az ágazatnak a gazdasági szerkezetváltásban kulcsfontosságú a szerepe - az iparra fókuszál. Már az 1990-es évek átalakulásánál megállapítható volt a kiemelt regionális centrumok (Miskolc, Debrecen, Szeged, Pécs, Győr) iparának eltérő átalakulási dinamikája. Egyik pólusán a legmélyebb szerkezeti válságot megélt nehézipari fellegvárral, Miskolccal, a másik pólusán a külföldi tőkebefektetések által ipari funkcióiban megerősödött Győrrel, miközben csökkent az ipar foglalkoztatási szerepe. Több helyen a zöldmezős beruházások új ipari tereket hoztak létre, a szerkezetváltás intenzitásától függően a leépülő régi ipar helyét újrahasznosításra váró rozsdaövezetek foglalták el (Kiss 2010). A külföldi múködő tőke beruházásaira épülő, gyakran delokalizációs/relokációs folyamatokkal összekapcsolódó újraiparosodás az Észak-Dunántúl és Közép-Magyarország kedvező helyzetét - vizsgált városaink közül Győr és Székesfehérvár dinamikus, az autóiparban és 
az elektronikai iparban betöltött szerepét - eredményezte (Kukely 2008), és egyúttal a nagyvállalati szektor markáns jelenlétéhez vezetett a régió megyéiben és nagyvárosaiban (Szabó 2017). A globális válság iparra gyakorolt hatásait összegző írások a recesszió hatásainak területi egyenlőtlenségeire, a sikeresebb városokban mutatkozó nagyobb arányú (utóbb átmenetinek bizonyult) visszaesésekre hívták fel a figyelmet (Barta-Lőcsei 2011, Kiss 2011). Ezekből már kiolvashatók a globális hálózatokba integrálódást és a külső gazdasági kitettséget érintő kritikai megközelítések is. Szisztematikus, ipari szerkezetet taglaló áttekintés is kötődik a nagyvárosokhoz. Ez a megyei jogú városok 2003-ban lehatárolt településegyütteseinek szintjén, az Európai Unió klaszterek beazonosítására használt módszertanára és a KSH Cég-KódTárából származó vállalati adatokból levezetett alkalmazottilétszám-becslésekre alapozva állapítja meg, hogy sok nagyváros markáns specializációval, potenciális ipari klaszterekkel rendelkezik. Az elemzésünk szempontjából releváns városok közül Kecskemét és Szeged élelmiszeripari orientációját, Miskolc fémipari, Nyíregyháza gumi- és műanyagipari profilját, Győr jármúipari, továbbá Székesfehérvár fémés jármúipari karakterét emelhetjük ki (Vas et al. 2015).

A szolgáltatásokat érintő kutatások - különösen a tudásigényes gazdasági szolgáltatások esetében - a szektor nagyarányú térbeli (fốvárosi) koncentrációját mutatják a 2000-es években, melyet a fogyasztók tömörülése, a képzett munkaerő, a személyes kapcsolatok, a közlekedési és a kommunikációs infrastruktúra egyenlőtlen fejlődése, továbbá az ágazat egyes elemeinek intézményi közszolgáltatásokhoz történő erős kötődése határoz meg. Miközben a szolgáltatások telephelyválasztására hatással volt a városhierarchia, az egyes hierarchiaszinteken belül is differenciálódás figyelhető meg. Vizsgált városaink közül két, ipari funkcióiban is erôs települést (Győr, Székesfehérvár), valamint két felsőoktatási központot (Pécs, Szeged) nevesítenek pozitív példaként az ingatlanügyletek és a gazdasági szolgáltatások ezredfordulós állapota alapján. Az ágazat erős térbeli koncentrációját, Budapesten kívül a nagyvárosok szerepét a tudásintenzív szolgáltatások - nemzetközi vállalatok által koordinált - régiókba irányuló kiszervezése, valamint egyes szolgáltatások centralizált szervezeti háttere tovább fokozta (Nagy 2003, Nagy E.-Nagy G. 2009). A klasszikus ágazati kereteken túlmutató kreatív gazdaság - hagyományos kulturális gazdaság és tudásintenzív ágazatok (infokommunikáció, pénzügyi, jogi és egyéb üzleti szolgáltatások, $\mathrm{K}+\mathrm{F}$, felsőoktatás) - földrajza a Budapesti agglomeráció után a legnagyobb vidéki városok (Debrecen, Szeged, Pécs, Győr, Székesfehérvár, Miskolc, Kecskemét, illetve tőlük kissé elmaradó Nyíregyháza) fölényét mutatja, nemcsak az abszolút mutatók, hanem - az egyetemvárosok és Székesfehérvár esetében - a kreatívnak minősített gazdasági tevékenységek relatív aránya alapján is (Kovács et al. 2011).

Végül az egy-egy város gazdaságára fókuszáló átfogó tanulmányok, illetve ágazativállalati esettanulmányok gyakorisága meglehetősen változó. Talán Győr feldolgozottsága a legalaposabb. Egyrészt az elmúlt évtizedben - számos tanulmány mellett főként a Győri Jármúipari Körzet kutatása kapcsán készült monográfiasorozat helyi

Területi Statisztika, 2018, 58(6): 610-637; DOI: 10.15196/TS580604 
gazdasághoz kapcsolódó kötetei (Honvári (szerk.) 2014, Lados (szerk.) 2014), illetve a helyi gazdaság kutatásának eredményeit a területi tóke elméleti kontextusában öszszefoglaló munka (Rechnitzer 2016) emelhető ki. A többi városról is vannak átfogó, hosszabb történelmi korszakot felölelő, esetleg helyi területi összefüggéseket kiemelő elemzések: Kecskemét (Kanalas 2016), Nyíregyháza (Kókai 2004), Pécs (Faragó 2010), Szeged (Boros 2009), Székesfehérvár (Molnár 2004). Másrészt, a nagyvárosok eltérő gazdasági szerkezetéből adódóan különböző ágazatok reprezentációja figyelhetô meg. Hiányos ismeretek birtokában sem megalapozatlan az állítás, miszerint a Kecskeméttel (Marsa 2002, Juhász-Lengyel 2016) és Miskolccal (Józsa 2014) foglalkozó elemzések középpontjában inkább az ipar áll, míg Pécsett a kultúra, a turizmus és az egyetem (Aubert et al. 2010, Gonda-Csapó 2014, Gál 2016), Szegeden a helyi tudományos életre épülő gazdasági tevékenységek (Vas 2009, Lengyel et al. 2018) kaptak nagyobb figyelmet. Debrecenről a településmarketing megközelítésében készült átfogó elemzés (Kozma 1999), illetve egy-egy ágazat (Süli et al. 2006, Lengyel-Molnár 2015) vagy gazdasági funkciójú terület (Kádár-Kozma 2011, Molnár 2013) is az érdeklődés középpontjába került. A vidéki nagyvárosok gazdasági szerkezetében megfigyelhető különbségek az ezredforduló óta Barta (2005), illetve Ambrus és szerzőtársai (2008) írásaiban is megjelentek.

\section{A nagyvárosok gazdasági dinamikája}

A nagyvárosok gazdasági teljesítményének összehasonlító elemzését két mutató, a települési gazdasági erő és a kettős könyvvitelt vezető társas vállalkozások összesített bruttó hozzáadott értéke alapján végeztük el. Míg az előbbi három komponens (regisztrált vállalkozások, helyi adóbevételek és adóköteles jövedelmek) alapján, a megyei GDP értékek dezaggregálásával létrehozott becsült érték, addig az utóbbi a NAV adatbázisában hozzáférhető, kettős könyvvitelt végző társas vállalkozások adatszolgáltatására épülő mutató, ami vállalati szinten megfelel a GDP értékének. A két mutató alapján számolt teljesítményekben több ok miatt is jelentős a különbség. Előbbi a teljes vállalkozói szféra mellett - jövedelemmutató és helyi adó alapján - az egyéb területen dolgozók által képviselt gazdaságot is felöleli, míg utóbbi csak a vállalkozások egy meghatározó, de nem teljes körét veszi számításba. Korábbi szakirodalmi tapasztalataink alapján megerősíthető, hogy a közigazgatási, oktatási, egészségügyi és szociális intézmények teljesítményének számításba vétele hatással van a városok abszolút és egymáshoz viszonyított helyzetének alakulására, elsősorban az intézményi-funkcionális szempontból fejlettebb regionális központokat (Debrecen, Szeged, Pécs) kedvezőbb pozícióba hozva. Továbbá, a települési GDP becslése során a helyi székhelyú vállalkozások nem helyben realizált teljesítményeit kiiktatják, a máshol székhellyel rendelkező cégek telephelyeit számításba veszik, míg a vállalkozási adatokat székhely szerint tartják nyilván, s így növelik a székhelyhatás torzító szerepét.

Területi Statisztika, 2018, 58(6): 610-637; DOI: 10.15196/TS580604 
A települési gazdasági erő abszolút értéke (Budapest értékének százalékában)

1. ábra

Absolute value of the economic strength of settlements (as a percentage of the value of Budapest)

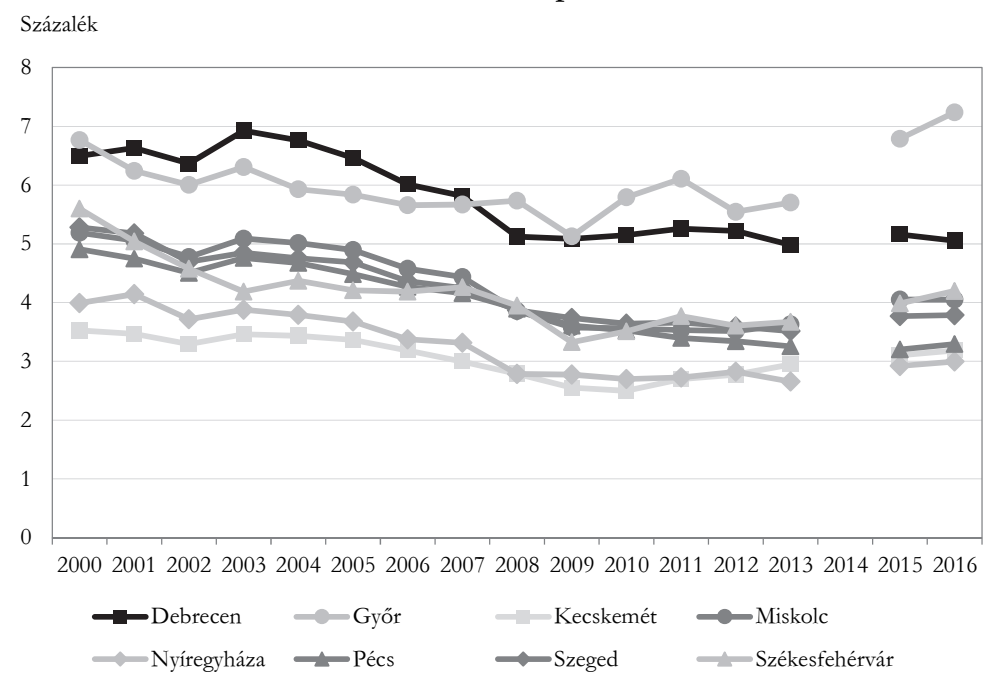

Forrás: KSH, NAV és MÁK adatai alapján a szerzők számítása.

A kettős könyvvitelt vezető társas vállalkozások bruttó hozzáadott értéke (Budapest értékének százalékában)

Gross value added of enterprises using the double-entry bookkeeping system (as a percentage of the value of Budapest)

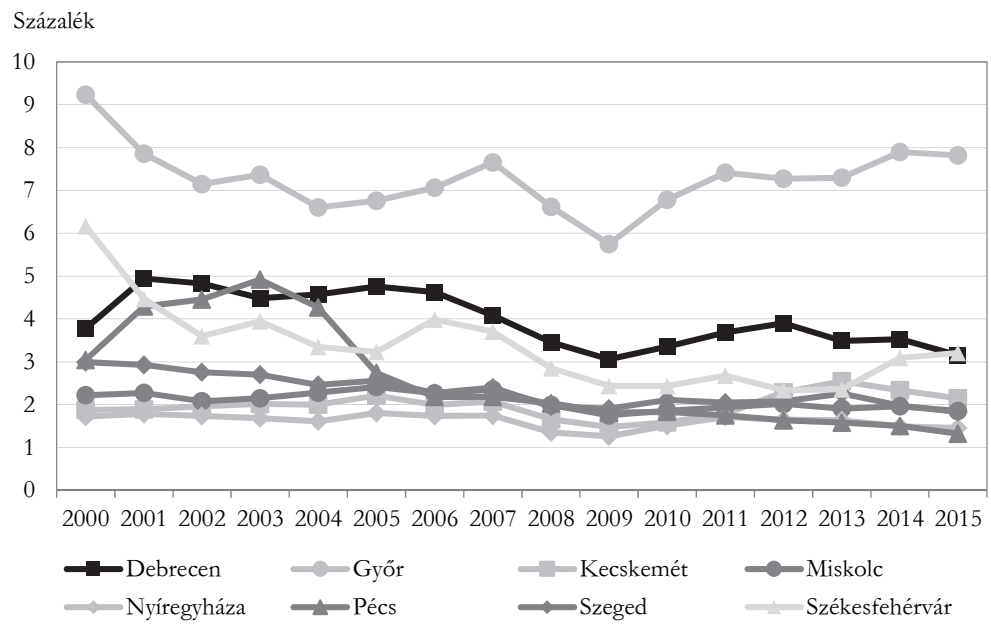

Forrás: NAV adatai alapján a szerzők számítása.

Területi Statisztika, 2018, 58(6): 610-637; DOI: 10.15196/TS580604 
Eredményeink alátámasztották fenti érvelésünket. Míg a települési gazdasági erőnél Debrecen és Győr versenye határozta meg a vizsgált idôszakot, az ezredfordulót követő években Magyarország második legnépesebb városa átmenetileg a települési GDP becsült értéke alapján is képes volt elfoglalni ezt a pozíciót, addig a helyi székhelyú kiemelt vállalati teljesítményeket mutató bruttó hozzáadott érték alapján megkérdőjelezhetetlen (a mezőnytől eltávolodó, kisebb visszaesést csak a gazdasági válság idején produkáló) Győrr elsősége. A második helyért Debrecen és Székesfehérvár - a korszak elején Pécs! - versenye figyelhetô meg. A kisebb városok esetében a települési gazdasági erő mutatójánál Kecskemét és Nyíregyháza utolsó előtti helyért folytatott vetélkedése jellemző. Előbbi a Mercedes gyár felfutásával lép utóbbi elé, illetve közelíti meg napjainkra Pécs teljesítményét. A bruttó hozzáadott érték alapján Kecskemét látványos előretörése figyelhető meg, míg a sor végére 2015-ben - Nyíregyháza előrébb lépésével - Pécs került. További következtetések levonására is lehetőséget adnak ábráink, melyeken a nagyvárosok gazdasági teljesítményét Budapesthez viszonyítva adtuk meg. Egyrészt, figyelemre méltó településeink gazdaságának fővároshoz képest mérhető egyenként kis aránya. A települési gazdasági erő többnyire a budapesti érték 3-7\%-a, a bruttó hozzáadott érték a fóváros teljesítményének 1,5-8\%-a között ingadozik. Másrészt, nem látszik a vidéki nagyvárosok és a fóváros mutatóiban a közeledés. A nyolc nagyváros összesített aránya 2000-ben volt a legnagyobb (a települési GDP esetében 40\% feletti, a bruttó hozzáadott értéknél 30\% feletti), illetve - a sikeresebb vidéki városok válság általi nagyobb érintettségének következtében 2009-ben a legkisebb (30\%, valamint 20\% alatti mutató). Ez - a székhelyhatás fővárost preferáló karaktere mellett is - a hazai gazdasági tér egypólusú jellegét, a Budapestet legalább részben ellensúlyozó vidéki központok hiányát jelzi (1-2. ábra). (A települési GDP adatsora azért hiányos, mert a 2014. évre vonatkozó, települési és megyei szinten aggregált helyi adóbevételek adatai nem álltak rendelkezésünkre, így egységes módszertannal nem tudtuk elvégezni a számítást.)

1. táblázat

A települési gazdasági erő és a bruttó hozzáadott érték egy lakosra jutó értéke Gross domestic product and gross value added of settlements per inhabitant

(millió forint/fő)

\begin{tabular}{l|c|c|c|c}
\hline \multirow{2}{*}{ Városok } & \multicolumn{2}{|c|}{ Települési GDP } & \multicolumn{2}{c}{ Bruttó hozzáadott érték } \\
\cline { 2 - 5 } & 2000 & 2015 & 2000 & 2015 \\
\hline Debrecen & 1,46 & 3,18 & 0,54 & 2,25 \\
Győrr & 2,43 & 6,55 & 2,12 & 8,75 \\
Kecskemét & 1,53 & 3,47 & 0,52 & 2,79 \\
Miskolc & 1,30 & 3,20 & 0,36 & 1,70 \\
Nyíregyháza & 1,58 & 3,09 & 0,44 & 1,79 \\
Pécs & 1,42 & 2,76 & 0,56 & 1,32 \\
Szeged & 1,49 & 2,90 & 0,54 & 1,64 \\
Székesfehérvár & 2,49 & 5,08 & 1,75 & 4,73 \\
Budapest & 2,65 & 7,10 & 1,69 & 8,24 \\
\hline
\end{tabular}

Forrás: KSH, NAV és MÁK adatai alapján a szerzők számítása.

Területi Statisztika, 2018, 58(6): 610-637; DOI: 10.15196/TS580604 
Az abszolút teljesítmények összevetésének eredményéhez két kiegészítés kapcsolódik. Egyrészt, a lakosságszámra vetített fajlagos mutatók a gazdasági potenciálokról alkotott képtől kissé eltérnek. A korszak elején és végén is egyértelmúen kiemelkedik Győr és Székesfehérvár: fölényük a bruttó hozzáadott érték alapján nagyobb, mint a települési GDP-nél. E két városhoz képest a többi nagyváros közti különbség a vizsgált időszak elején és végén is csekély. Szembetűnő ugyanakkor, hogy az ezredfordulón még (a rendszerváltás után mély szerkezeti válságot átélt) Miskolc állt az utolsó helyen, majd 2015-re Pécs foglalta el e pozíciót, illetve 2015-re Kecskemét mindkét mutató fajlagos értéke alapján harmadik helyre került. Budapest egy lakosra jutó települési GDP értékei meghaladták valamennyi nagyváros mutatóját a vizsgált időszak elején és végén is, míg a lakosságszámra vetített bruttó hozzáadott érték alapján a fơváros csak Győrtől maradt el kissé (1. táblázat). Budapest fölénye nemcsak a nagyobb abszolút méretében, hanem a vidéki városok mindegyikét meghaladó fajlagos mutatóiban is látható.

Másrészt, a nagyvárosok közigazgatási területére szúkített vizsgálat csak részben tükrözi e gazdasági tömörülések valódi arányát. Az agglomerációs gazdaságosság szempontjából indokoltnak tűnik egy olyan összehasonlítás, mely a nagyvárosi településegyüttesek egészének gazdasági teljesítményét számításba veszi. Elemzésünk egyik tanulsága, hogy az egyes nagyvárosokhoz eltérő arányú „hátországok” kapcsolódnak, melyek szerepe - legalábbis a települési GDP becsült értékei alapján - egyértelmúen növekvő. (Míg a települési GDP - elsősorban az adóköteles jövedelmek révén - felértékeli az ingázókat kibocsátó települések teljesítményét, addig a kizárólag helyi székhelyú vállalatok adatait tartalmazó bruttó hozzáadott érték a gazdasági szereplők jelentős részét tömörítő központi településnek kedvez.) A központon kívüli települések a győri és a miskolci agglomerációban, továbbá a székesfehérvári településegyüttesben növelik leginkább a településegyüttes egészének gazdasági arányát, ami az érintett települések száma és az ingázás e térségekben jellemző intenzitása (Pénzes et al. 2015, Pálóczi 2016) alapján sem meglepó. További eredménye a vizsgálatnak, hogy a településegyüttes-szintű teljesítmény még nagyobb, és a vizsgált időszakban növekvő különbségeket mutat. Győr dominanciája itt erősebb, mint a városi adatok alapján, míg Miskolc - jelentôs hátországának köszönhetően, a települési GDP alapján - Debrecenhez és Székesfehérvárhoz hasonló arányú szereplővé vált. Budapesthez a településegyüttes-szintú adatok alapján sem kerülnek közelebb arányaikban a vidéki nagyvárosok, ráadásul Győr (települési gazdasági erő) és Kecskemét (bruttó hozzáadott érték) kivételével másfél évtized alatt inkább romlottak a pozícióik (2. táblázat).

Területi Statisztika, 2018, 58(6): 610-637; DOI: 10.15196/TS580604 
Települési gazdasági erő és bruttó hozzáadott érték az agglomerálódó térségekben

Gross domestic product and gross value added of settlements in the agglomerating regions

\begin{tabular}{|c|c|c|c|c|}
\hline \multirow{2}{*}{$\begin{array}{c}\text { Agglomerálódó } \\
\text { térség }\end{array}$} & \multicolumn{2}{|c|}{ Települési GDP } & \multicolumn{2}{|c|}{ Bruttó hozzáadott érték } \\
\hline & 2000 & 2015 & 2000 & 2015 \\
\hline \multicolumn{5}{|c|}{ A központ értékének \%-ában } \\
\hline Debrecen & 109,0 & 114,0 & 103,0 & 104,0 \\
\hline Győr & 130,0 & 153,0 & 103,0 & 105,0 \\
\hline Kecskemét & 107,0 & 110,0 & 113,0 & 113,0 \\
\hline Miskolc & 127,0 & 151,0 & 113,0 & 112,0 \\
\hline Nyíregyháza & 109,0 & 121,0 & 103,0 & 103,0 \\
\hline Pécs & 110,0 & 140,0 & 103,0 & 107,0 \\
\hline Szeged & 116,0 & 123,0 & 113,0 & 108,0 \\
\hline Székesfehérvár & 121,0 & 150,0 & 101,0 & 105,0 \\
\hline \multicolumn{5}{|c|}{ A Budapesti agglomeráció \%-ában } \\
\hline Debrecen & 6,0 & 4,8 & 3,4 & 2,9 \\
\hline Győr & 7,5 & 8,6 & 8,4 & 7,3 \\
\hline Kecskemét & 3,2 & 2,8 & 1,9 & 2,2 \\
\hline Miskolc & 5,6 & 5,0 & 2,2 & 1,8 \\
\hline Nyíregyháza & 3,7 & 2,9 & 1,6 & 1,3 \\
\hline Pécs & 4,6 & 3,7 & 2,8 & 1,3 \\
\hline Szeged & 5,2 & 3,8 & 3,0 & 1,8 \\
\hline Székesfehérvár & 5,8 & 4,9 & 5,5 & 3,0 \\
\hline
\end{tabular}

Megjegyzés: Az agglomerálódó térségek (agglomerációk és településegyüttesek) adatait a KSH 2014. évi lehatárolása alapján számoltuk - az összehasonlíthatóság érdekében - változatlan határokkal mindkét időpontban.

Forrás: KSH, NAV és MÁK adatai alapján a szerzők számítása.

Az eltérő gazdasági teljesítmények mögött különböző és változó szerkezetek húzódnak meg. Az exportárbevétel aránya erős kapcsolatot mutat a külföldi tôkebefektetések intenzitásával és alkalmas a nemzetközi termelési hálózatokba kapcsolódás jelentőségének kifejezésére, ami jelentősen differenciálja a nagyvárosi gazdaságokat. Mindvégig kiemelkedik az ezredforduló utáni időszakban Győr és Székesfehérvár, míg a korszak elején aránylag kis különbségeket mutató többi város különböző irányokba fejlődik. Kecskemét - 70\%-ot megközelító értékkel - Győrhöz és Székesfehérvárhoz hasonló exportorientációt ért el a korszak végére, míg Nyíregyházából, Miskolcból és Debrecenből - 30, illetve 40\% körüli értékekkel - középmezőny formálódott, Szeged és Pécs a 15\% körüli értékeivel a nagyvárosi és az országos átlagtól elmaradó külpiaci integráltságot mutatott (3. ábra). A munkatermelékenységre használt mutató (egy foglalkoztatottra jutó nettó árbevétel) időbeli alakulása részben eltérő. Bár ezúttal is a külföldi múködő tőke preferált városai állnak a fejlettségi rangsor élén, Székesfehérvár pozíciója erősen ingadozó. A „középmezőnyben” - a korszak végén - alig van különbség Debrecen, Miskolc, Nyíregyháza és Szeged értékei között, csak Pécs értékei mutatnak nagyobb arányú elmaradást a többi várostól (4. ábra).

Területi Statisztika, 2018, 58(6): 610-637; DOI: 10.15196/TS580604 
Az exportárbevétel aránya

Ratio of export sales, percentage

Százalék

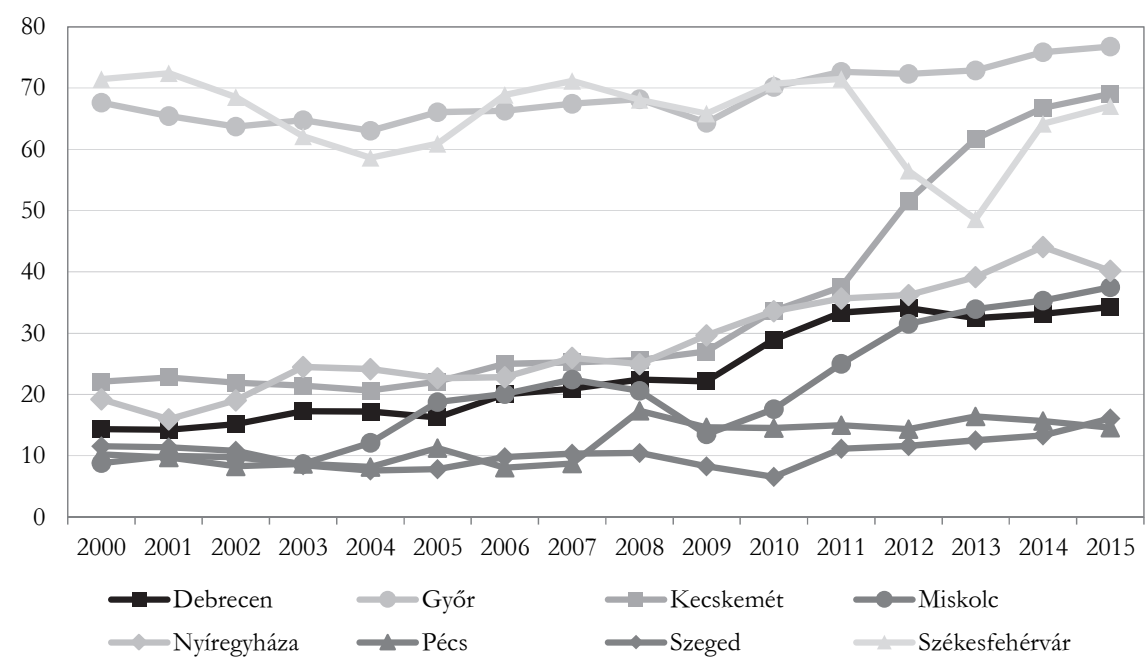

Forrás: NAV adatai alapján a szerzők számítása.

4. ábra

Egy foglalkoztatottra jutó nettó árbevétel a csoportátlag* százalékában

Net sales per employee in percentage of the group average

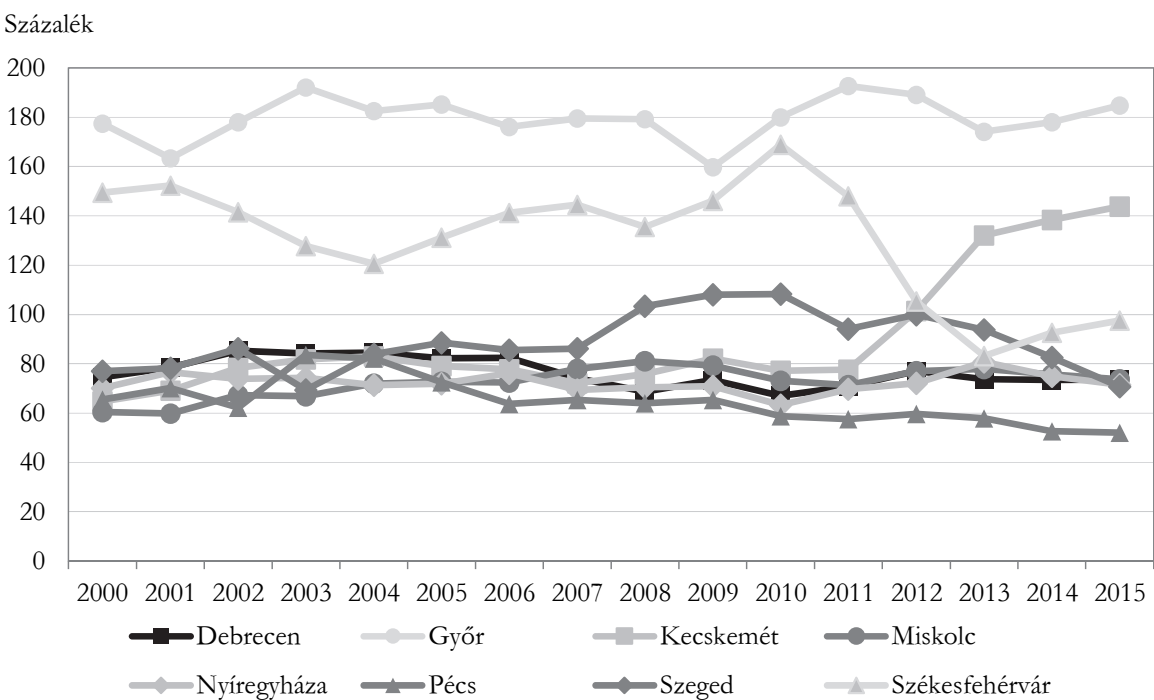

* Az elemzésben szereplő nyolc vidéki nagyváros átlaga.

Forrás: NAV adatai alapján a szerzők számítása.

Területi Statisztika, 2018, 58(6): 610-637; DOI: 10.15196/TS580604 
Egészen más eredményeket kapunk, ha megvizsgáljuk a bruttó hozzáadott érték teljes kibocsátáson belüli arányát. A mutató magas és növekvő értéke a nemzetközi hálózatok keretében végzett helyi értékteremtés jelentős arányát, a funkcionális feljebb lépés (Humphrey-Schmitz 2002, Barrientos et al. 2011, Szalavetz 2012) folyamatát mutatná, azonban a helyzet meglehetősen felemás. Épp a kiemelkedő gazdasági teljesítményt, nagy exportorientációt és termelékenységet képviselő városok esetében kisebb arányaiban a helyi hozzáadott érték. Székesfehérvár a vizsgált időszak jelentős részében, míg Kecskemét - a nagy gazdasági „nekilendüléssel” a korszak végén a 20\%-ot sem érte el. 40\%-ot meghaladó értékeket tartósan csak (a minden eddigi mutatójában gyengén teljesítő) Pécs, valamint a középmezőnybe sorolható Debrecen és Nyíregyháza ért el. Mindez - Székesfehérvár erősen ingadozó termelékenységi mutatóival együtt - napjainkban is a külföldi múködő tőkére épülő modernizációs modell strukturális gyengeségeit, a sikerek sérülékenységét mutatja (5. ábra).

\section{A bruttó hozzáadott érték aránya a kibocsátás értékéből}

Share of gross value added in the value of output, percentage

Százalék

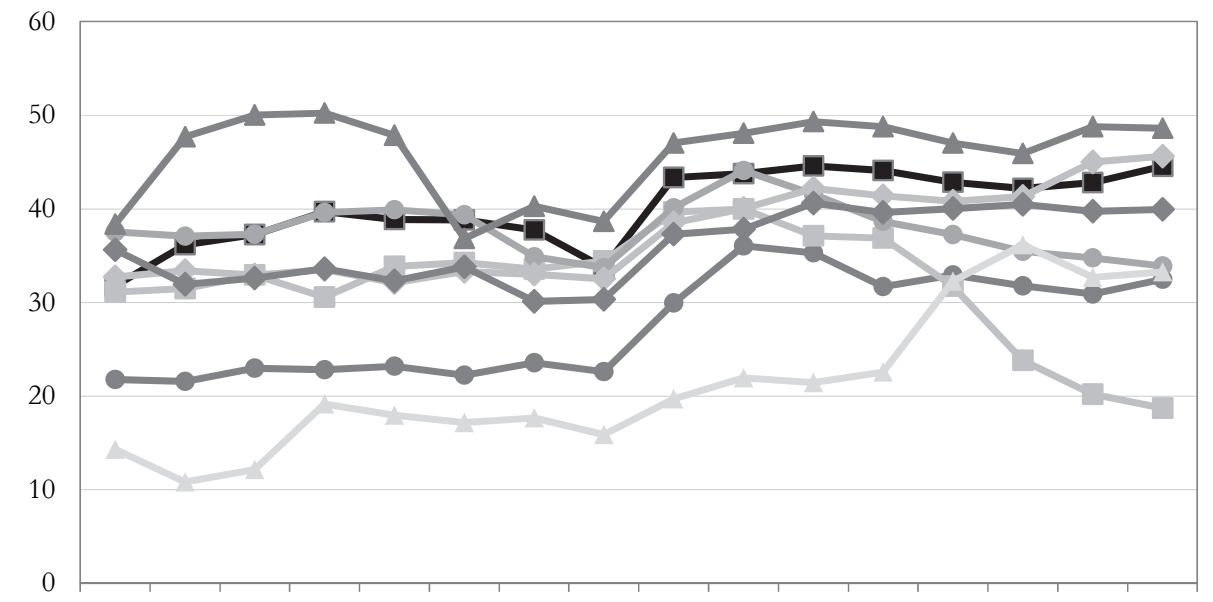

2000200120022003200420052006200720082009201020112012201320142015

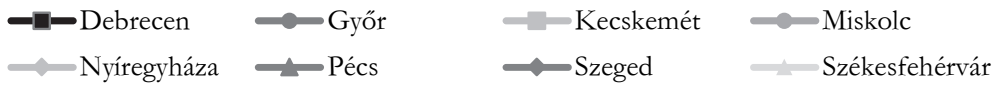

Forrás: NAV adatai alapján a szerzők számítása.

Területi Statisztika, 2018, 58(6): 610-637; DOI: 10.15196/TS580604 


\section{A nagyvárosok gazdasági szerkezete}

Nagyvárosainkban az ezredforduló utáni másfél évtizedet a regisztrált vállalkozások folyamatos gyarapodása mellett - 2003, illetve 2004 után - a működő vállalkozások és társas vállalkozások számának csökkenése-stagnálása határozta meg. Összevetve az időszak elejét és végét, a nagy-, közép- és potenciális középvállalatok abszolút száma csökkent, míg a múködő társas vállalkozásokon belüli arányuk mérsékelten nőtt. A nagy- és középvállalatok összesített száma csak Debrecenben gyarapodott (Pécsett az ezredforduló óta megfeleződött), míg a potenciális középvállalatok száma Székesfehérváron és Kecskeméten látványosan bővült, de Szegeden és Debrecenben is emelkedett. Emellett a múködő társas vállalkozások ágazati szerkezete a szolgáltatások felé tolódott. A primer és szekunder szektor múködő társas vállalkozásainak száma mindenütt csökkent, miközben a termelő szektor arányaiban fennálló városok közti különbségek megmaradtak. A mezőgazdasági vállalkozások nagyobb arányával jellemezhető három alföldi nagyváros (Debrecen, Kecskemét, Nyíregyháza), míg az ipari-építőipari vállalkozások nagyobb aránya figyelhető meg Kecskeméten és Székesfehérváron (2016-ban már Győrben és Nyíregyházán is). A hagyományos termelő ágazatok nagyobb arányával jellemezhető kisebb nagyvárosok ellentétét a jelentős regionális funkciókkal rendelkező két felsőoktatási központ (a 2011. évi népszámlálási adatok alapján is erősen tercierizálódott) Szeged és Pécs képezte (3. táblázat).

3. táblázat

\section{A működő vállalkozások néhány jellemzője a vizsgált magyarországi nagyvárosokban}

Some features of the enterprises operating in the Hungarian minor cities examined

\begin{tabular}{l|c|c|c|c|c|c}
\hline \multirow{2}{*}{$\begin{array}{l}\text { Városok } \\
\text { Debrecen }\end{array}$} & \multicolumn{2}{|c|}{$\begin{array}{c}\text { Múködő társas } \\
\text { vállalkozások száma, } \\
\text { darab }\end{array}$} & \multicolumn{2}{c|}{$\begin{array}{c}\text { Múködő nagy-, közép- és } \\
\text { potenciális közép- } \\
\text { vállalatok aránya, } \%\end{array}$} & \multicolumn{2}{c}{$\begin{array}{c}\text { Szolgáltató szektoron } \\
\text { kívül múködő társas } \\
\text { vállalkozások aránya, \% }\end{array}$} \\
\cline { 2 - 7 } & 2000 & 2016 & 2000 & 2016 & 2000 & 2016 \\
\hline Győr & 9425 & 9357 & 3,6 & 3,7 & 21,5 & 18,4 \\
Kecskemét & 6392 & 5827 & 4,7 & 4,8 & 19,0 & 18,8 \\
Miskolc & 4902 & 5085 & 4,5 & 4,7 & 24,3 & 19,9 \\
Nyíregyháza & 7656 & 5889 & 3,3 & 3,4 & 18,7 & 18,7 \\
Pécs & 5574 & 5014 & 4,1 & 4,0 & 21,4 & 20,8 \\
Szegged & 8562 & 6686 & 3,1 & 3,0 & 19,9 & 17,1 \\
Székesfehérvár & 7929 & 7194 & 3,4 & 3,9 & 18,0 & 16,5 \\
Összesen & 5377 & 4798 & 4,6 & 5,5 & 24,0 & 20,6 \\
\hline
\end{tabular}

Forrás: KSH adatai alapján a szerzők számítása.

Területi Statisztika, 2018, 58(6): 610-637; DOI: 10.15196/TS580604 
A KSH 2013-ból rendelkezésünkre álló, nagyságrendi és ágazati adatok kombinált elemzését lehetôvé tevő vállalati adatbázisának adatai alapján kijelenthető, hogy a gazdasági potenciál szempontjából meghatározó nagy- és középvállalatok száma Debrecenben és Győrben a legnagyobb, lakosságszámra vetített sűrűségük alapján Székesfehérvár és Győr teljesítménye kiemelkedő. Ezzel szemben, a vállalati teljesítményközpontú mutatók alapján a gyengén teljesítő városokban a nagy- és középvállalatok viszonylag kis számban vannak jelen. Ez a potenciális középvállalatok figyelembevételével is csak részben változott. Eltérés a két vállalatcsoporthoz kötődő teljesítményben leginkább Debrecenben és Nyíregyházán figyelhető meg, ahol a nagy- és középvállalatok átlagos vagy átlag alatti sưrűsége a potenciális középvállalatok lakosságszámra vetített magas értékeivel párosult. Ez utal a két város gazdaságában rejlő lehetőségekre, a nagyvállalati szereplők vonzására építő gazdaságfejlesztési stratégiák mellett a helyi kisvállalatok erôsítésére fókuszáló beavatkozások indokoltságára. A potenciális középvállalatok nagy- és középvállalatok számához mérhető aránya az egyetemvárosokban és Nyíregyházán megközelítette vagy meghaladta a kétszeres értéket, míg Győrben és Székesfehérváron alig volt nagyobb egynél. A feldolgozóipari szereplők erős jelenléte figyelhető meg a nagy- és középvállalati szegmensben, illetve a kedvezőbb mutatókat produkáló városok közül Kecskeméten és Székesfehérváron. Legkevésbé ipari jellegú Debrecen és Szeged gazdasága, bár a helyi vállalkozások számából adódóan elóbbi a feldolgozóipari nagy- és középvállalatok terén Győr és Székesfehérvár után következett, a szektorhoz kötődő potenciális középvállalatok abszolút számában pedig egyértelmủ listavezető volt (4. táblázat).

4. táblázat

\section{A nagy-, közép- és potenciális középvállalatok abszolút száma és lakosságszámra vetített értéke a magyarországi nagyvárosokban}

The absolute number of large, medium-sized and potential medium-sized enterprises and their number per ten thousand inhabitants in the Hungarian minor cities

\begin{tabular}{l|c|c|c|c|c|c}
\hline \multirow{2}{*}{ Városok } & \multicolumn{2}{c|}{$\begin{array}{c}\text { Vállalkozások száma, } \\
\text { darab }\end{array}$} & \multicolumn{2}{c}{$\begin{array}{c}\text { Vállalkozások száma } \\
\text { tízezer lakosra, darab }\end{array}$} & \multicolumn{2}{c}{$\begin{array}{c}\text { Feldolgozóipari } \\
\text { vállalkozások aránya, \% }\end{array}$} \\
\cline { 2 - 7 } & $\begin{array}{c}50 \text { fón } \\
\text { feletti }\end{array}$ & $20-49$ fös & $\begin{array}{c}50 \text { fón } \\
\text { feletti }\end{array}$ & $20-49$ fös & 50 fö feletti & $20-49$ fös \\
\hline Debrecen & 130 & 256 & 6,4 & 12,6 & 33,0 & 26,0 \\
Győr & 129 & 148 & 10,0 & 11,5 & 38,0 & 27,0 \\
Kecskemét & 84 & 148 & 7,5 & 13,2 & 48,0 & 29,0 \\
Miskolc & 80 & 123 & 5,0 & 7,6 & 40,0 & 26,0 \\
Nyíregyháza & 71 & 165 & 6,0 & 14,0 & 38,0 & 27,0 \\
Pécs & 60 & 152 & 4,1 & 10,4 & 40,0 & 24,0 \\
Szeged & 85 & 173 & 5,2 & 10,7 & 33,0 & 19,0 \\
Székesfehérvár & 100 & 138 & 10,1 & 13,9 & 44,0 & 31,0 \\
Összesen & $\mathbf{7 3 9}$ & $\mathbf{1 3 0 3}$ & $\mathbf{6 , 5}$ & $\mathbf{1 1 , 5}$ & $\mathbf{3 9 , 0}$ & $\mathbf{2 6 , 0}$ \\
\hline
\end{tabular}

Forrás: KSH Cég-Kód-Tár adatai (2013) alapján a szerzők számítása. 
5. táblázat

Kiemelkedő gazdasági ágak a nagy- és középvállalatok abszolút száma, illetve a gazdasági ágak relatív felülreprezentáltsága alapján, 2013

Outstanding economic sectors based on the absolute number of large and medium-sized enterprises and the relative over-representation of such economic sectors, 2013

\begin{tabular}{|c|c|c|}
\hline Városok & Gazdasági tevékenységek & Darab \\
\hline Debrecen & $\begin{array}{l}\text { Kereskedelem, gépjárműjavítás }(\mathrm{G}) \\
\text { Adminisztratív és szolgáltatást támogató tevékenység }(\mathrm{N}) \\
\text { Élelmiszer, ital, dohánytermék gyártása }(\mathrm{CA})\end{array}$ & $\begin{array}{l}31 \\
16 \\
13\end{array}$ \\
\hline Győr & $\begin{array}{l}\text { Kereskedelem, gépjárműjavítás }(\mathrm{G}) \\
\text { Adminisztratív és szolgáltatást támogató tevékenység }(\mathrm{N}) \\
\text { Fémalapanyag és fémfeldolgozási termék gyártása }(\mathrm{CH}) \\
\text { Gumi-, műanyag és nemfém ásványi termék gyártása }(\mathrm{CG}) \\
\text { Építőipar }(\mathrm{F})\end{array}$ & $\begin{array}{r}21 \\
10 \\
10 \\
9 \\
9\end{array}$ \\
\hline Kecskemét & $\begin{array}{l}\text { Kereskedelem, gépjárműjavítás }(\mathrm{G}) \\
\text { Egyéb, erősen felülreprezentált: } \\
\text { Fafeldolgozás, papírtermék gyártása, nyomdai tevékenység (CC) } \\
\text { Villamos berendezés gyártása }(\mathrm{CJ})\end{array}$ & $\begin{array}{l}12 \\
6 \\
5\end{array}$ \\
\hline Miskolc & $\begin{array}{l}\text { Fémalapanyag és fémfeldolgozási termék gyártása }(\mathrm{CH}) \\
\text { Adminisztratív és szolgáltatást támogató tevékenység }(\mathrm{N}) \\
\text { Egyéb, erősen felülreprezentált: } \\
\text { Gép, gépi berendezés gyártása }(\mathrm{CK})\end{array}$ & $\begin{array}{l}13 \\
11 \\
6\end{array}$ \\
\hline Nyíregyháza & $\begin{array}{l}\text { Kereskedelem, gépjárműjavítás }(\mathrm{G}) \\
\text { Adminisztratív és szolgáltatást támogató tevékenység }(\mathrm{N}) \\
\text { Egyéb, erősen felülreprezentált: } \\
\text { Textília, ruházat, bőr és bőrtermék gyártása }(\mathrm{CB})\end{array}$ & $\begin{array}{r}12 \\
9 \\
5\end{array}$ \\
\hline Pécs & $\begin{array}{l}\text { Kereskedelem, gépjárműjavítás }(\mathrm{G}) \\
\text { Egyéb, erősen felülreprezentált: } \\
\text { Villamosenergia-, gáz-, gőzzellátás, légkondicionálás (D) } \\
\text { Textília, ruházat, bőr és bőrtermék gyártása (CB) }\end{array}$ & $\begin{array}{l}10 \\
4 \\
5\end{array}$ \\
\hline Szeged & $\begin{array}{l}\text { Kereskedelem, gépjárműjavítás }(\mathrm{G}) \\
\text { Egyéb, erősen felülreprezentált: } \\
\text { Mezőgazdaság, erdőgazdaság, halászat (A) }\end{array}$ & $\begin{array}{r}15 \\
6 \\
\end{array}$ \\
\hline Székesfehérvár & $\begin{array}{l}\text { Kereskedelem, gépjármújavítás }(\mathrm{G}) \\
\text { Adminisztratív és szolgáltatást támogató tevékenység }(\mathrm{N}) \\
\text { Fémalapanyag és fémfeldolgozási termék gyártása }(\mathrm{CH}) \\
\text { Egyéb, erősen felülreprezentált: } \\
\text { Számítógép, elektronikai, optikai termék gyártása }(\mathrm{CI}) \\
\text { Járműgyártás }(\mathrm{CL})\end{array}$ & $\begin{array}{r}15 \\
11 \\
9 \\
6 \\
7\end{array}$ \\
\hline
\end{tabular}

Forrás: KSH Cég-Kód-Tár adatai alapján a szerzők számítása.

Területi Statisztika, 2018, 58(6): 610-637; DOI: 10.15196/TS580604 
A nagy- és középvállalatok ágazati megoszlását vizsgálva látható, hogy a kereskedelem, gépjármújavítás $(\mathrm{G})$, illetve az adminisztratív és szolgáltatást támogató tevékenység $(\mathrm{N})$ jelentősége a városok többségében a cégek nagy létszámával is magyarázható. Nagy arányban vannak jelen, alátámasztva a tercierizáció irányába mutató trendek meglétét. Néhány város ugyanakkor egy-egy feldolgozóipari ágnak is jelentős tömörülése. Debrecenben az élelmiszeripar, Győrben - az autóiparhoz beszállítóként erősen kötődő - a fémipar, illetve a gumi- és műanyagipar, míg Miskolcon és Székesfehérváron - a helyi ipari tradíciókból következően - a fémipar nagy- és középvállalati jelenléte a meghatározó. Ha nemcsak a nagy- és középvállalatok abszolút számát, de bizonyos gazdasági tevékenységek felülreprezentáltságának mértékét is vizsgáljuk (ezen az elven alapul a potenciális klaszterek lehatárolásánál használt lokációs hányados számítása), akkor Kecskemét fa-, papír-, nyomdaipari, illetve villamosgép-gyártó, Miskolc gépipari, Nyíregyháza és Pécs textil-, ruha- és bőripari, Szeged mezőgazdasági, továbbá Székesfehérvár elektronikai és járműgyártó karaktere is látható, megerōsítve a témában írt korábbi tanulmányok tartalmát (5. táblázat).

A potenciális középvállalatok mindenütt a kereskedelem, gépjármújavítás, illetve az építőipar területén fordulnak elő nagyobb számban. Kiemelkedő ez alapján Szeged, ahol a vizsgált városok közül a legtöbb potenciális középvállalat ( 85 darab, a kategóriába tartozó helyi vállalkozások közel fele) múködött e két gazdasági ágban. Más városokban egyes hagyományos termelő ágazatokban is nagyobb számban jelentek meg potenciális középvállalatok. Debrecenben jelentős szereplő az élelmiszeripar, melynek a nagy-, közép- és potenciális középvállalatai - a helyi székhelyú, hasonló nagyságrendű kategóriákba tartozó mezőgazdasági szereplőkkel együtt - 40 feletti értéket adtak, alátámasztva a szektort érintő helyi klaszterépítési törekvések jogosságát. Győrben a nagy- és középvállalati szegmensben kiemelkedő két iparág (fémipar, gumi- és múanyagipar) utánpótlása volt a legerôsebb a potenciális középvállalatok körében is. Erôs a fémipar bázisa Miskolcon (közel 30 darab) és Székesfehérváron (25 darab), továbbá a textil-, ruha- és bőripar Pécsett (20 darab) a nagy-, közép- és potenciális középvállalatok összesített száma alapján. Mindez - az újraiparosodás eltérô intenzitása mellett - a hagyományos iparágakhoz kapcsolódó tudás továbbélését mutatja, mely több esetben helyi klaszterépítési törekvésekben (győri Pannon Autóipari Klaszter, Professio Fémipari és Szakképzési Klaszter, miskolci Észak-magyarországi Autóipari Klaszter, Pécsi Kesztyú Klaszter) is megjelenik.

A jelentős számú helyi vállalkozást tömörítő ágazatok között előfordult néhány szolgáltatás is. Debrecenben az adminisztratív és szolgáltatást támogató tevékenységek (N) és a szálláshely-szolgáltatás, vendéglátás (I), Győrben a szállítás, raktározás (H), Nyíregyházán és Székesfehérváron az adminisztratív és szolgáltatást támogató tevékenységek $(\mathrm{N})$ emelhetôk ki. A globális hálózatokba integrálódott szolgáltató központok több nagyváros - elsősorban Debrecen és Székesfehérvár - gazdaságában jelentős szereplővé váltak (egyenként 2500-3000 foglalkoztatott), azonban az ún. SSC szektor kereskedelmi láncokhoz vagy pénzügyi szféra fontosabb szereplői-

Területi Statisztika, 2018, 58(6): 610-637; DOI: 10.15196/TS580604 
hez hasonló szervezeti centralizáltság folytán, e cégek teljesítménye csak mérsékelten jelenik meg az érintett városok nagy- és középvállalati adataiban. Jellegzetes példa a budapesti székhellyel bejegyzett IT Services Hungary, mely - honlapja alapján 4500 főt foglalkoztat Magyarországon, közülük több mint 1600 fő Debrecenben, 330 fő Pécsett, 110 fő pedig Szegeden alkalmazottja a cégnek.

6. táblázat

A legalább 500 főt foglalkoztató helyi székhelyủ vállalkozások adatai

Data of locally based enterprises employing at least 500 persons

\begin{tabular}{l|c|c|c|l}
\hline \multicolumn{1}{c|}{ Városok } & $\begin{array}{c}\text { Cégek száma, } \\
\text { darab } \\
2018 . \text { év }\end{array}$ & $\begin{array}{c}\text { Árbevétel, } \\
\text { euróban } \\
2017 . \text { év }\end{array}$ & $\begin{array}{c}\text { Foglalkoztatot- } \\
\text { tak száma, fó } \\
\text { 2018. év }\end{array}$ & $\begin{array}{c}\text { Kiemelkedő } \\
\text { iparágak }\end{array}$ \\
\hline Debrecen & 12 & 1907304761 & 14166 & $\begin{array}{l}\text { Gyógyszeripar, } \\
\text { elektronika, } \\
\text { gépgyártás }\end{array}$ \\
\hline Győr & 16 & $\mathbf{8} \mathbf{8 9 2 6 1 5 4 5 6}$ & 24286 & $\begin{array}{l}\text { Jármúgyártás, } \\
\text { fémipar }\end{array}$ \\
\hline Kecskemét & 13 & 4422857759 & 14943 & $\begin{array}{l}\text { Jármúgyártás, } \\
\text { élelmiszeripar }\end{array}$ \\
\hline Miskolc & 11 & $\mathbf{2 0 7 7 2 3 0 4 1 1}$ & 17869 & $\begin{array}{l}\text { Jármúgyártás, } \\
\text { gépipar }\end{array}$ \\
\hline Nyíregyháza & 8 & 1088115093 & 9065 & $\begin{array}{l}\text { Gumi- és } \\
\text { múanyagipar, } \\
\text { játékgyártás }\end{array}$ \\
\hline Pécs & 6 & 452144940 & 5744 & Gépgyártás \\
\hline Szeged & 9 & 1250366191 & 7804 & Élelmiszeripar \\
\hline Székesfehérvár & 15 & $\mathbf{2 6 9 7 8 1 0 2 4 6}$ & 21848 & $\begin{array}{l}\text { Jármúgyártás, } \\
\text { fémipar, } \\
\text { elektronika, } \\
\text { élelmiszeripar }\end{array}$ \\
\hline
\end{tabular}

Megjegyzés: A dőlt betűvel szedett árbevételi adatok hiányosak.

Forrás: Creditreform Céginformáció.

Nemcsak a nagy-, közép- és potenciális középvállalati szektor egészében mutatkoznak különbségek a vizsgált városok között. Ha az 500 fő feletti vállalati foglalkoztatókat vesszük, a differenciák látványosabbak, és nagyban magyarázhatják a gazdasági potenciálokban mutatkozó különbségeket. Míg a cégek számában kétháromszoros, addig a foglalkoztatottak létszámában négyszeres, árbevételben pedig húszszoros különbség mutatkozott e vállalatkörben a listavezető Győr és a sereghajtó Pécs között. Miközben a négy kisebb népességszámú városban a kategóriába tartozó cégek fele-kétharmada, a foglalkoztatás háromnegyede és az árbevétel 90\%-a a feldolgozóiparhoz kapcsolódott, addig Szegednél e szektor aránya a mutatók több-

Területi Statisztika, 2018, 58(6): 610-637; DOI: 10.15196/TS580604 
ségében 50\%, Pécsett 35\% alatt marad. Szegeden és Pécsett az egyetem (közel 8500, illetve 7500 alkalmazásban állóval) önmagában nagyobb foglalkoztatónak számított 2018-ban, mint a 6. táblázatban szereplő helyi székhelyú nagyvállalatoknál összesen. Figyelemre méltók - a kiemelkedő vállalatok adatai alapján - az ipar ágazati diverzifikáltságának különbségei, valamint eltérései a vállalatok száma alapján megállapított iparági specializációktól (5-6. táblázat). A 2015. évi adatok alapján elvégzett számítások, mely szerint a győri székhelyú kettős könyvelést vezető vállalkozások nettó árbevételének kétharmada az Audihoz, Kecskeméten több mint fele a Mercedeshez kötődött, e sikeresebb települések relatíve egyoldalú, egy-egy kiemelkedő szereplőtől függő eredményeit mutatja. Utóbbi tényező nemcsak az összes árbevétel, az export vagy a termelékenység kiemelkedő adataiban, de a hozzáadott érték alakulásában is szerepet játszhat. Győ́r gazdasági recesszió után megemelkedett hozzáadott érték mutatóinak hátterében az Audi jármúgyárának kooperációs gyártási rendszerről történő átállása, a létesítmény komplett járműgyárrá fejlesztése valószínúsíthető, míg Kecskeméten a mutatók romlása az újonnan megtelepült, de egyelőre kismértékben beágyazódott Mercedes termelésének felfutásával magyarázható (5. ábra).

\section{Következtetések}

A vidéki nagyvárosok gazdaságát különböző szempontokból vizsgáló elemzésünkből fontos következtetések vonhatók le. (1) A jelentős gazdasági potenciált és dinamikát felmutató települések a külföldi múködő tôke - elsősorban nagyvállalati szektorban megfigyelhetô - masszív jelenlétével, a nemzetközi termelési hálózatokba történő erősebb integrációval jellemezhetôk. (2) Nem látszik más bázisképzési alternatíva nagyvárosaink esetében, mint a feldolgozóipar. Választott teljesítménymutatóink magas, illetve növekvő értékei a feldolgozóipari szereplők nagyberuházásaihoz kötődtek. Ahol nem volt ipari megújulás, ott az egyéb irányú gazdaságfejlesztési törekvések ellenére sem látszik az újraerősödés. (3) A külföldi múködő tőke nagyvállalati (ipari) szereplői által meghatározott városi sikereknek ugyanakkor nem örülhetünk maradéktalanul. A helyi hozzáadott érték e városokban volt a legalacsonyabb, ráadásul mind Győr, mind Kecskemét gazdasági mutatói hátterében egyetlen kiemelkedô szereplő áll, ami a nemzetközi termelési hálózatokba integrálódás egyoldalúságát, a helyi gazdaság sérülékenységét mutatja. Győr és Székesfehérvár gazdaságában arányaiban kevés a potenciális középvállalat, ami a nagy cégek helyi beágyazódása szempontjából fontos kapcsolatépítési lehetőségeket korlátozhatja. Eredményeink nemcsak megerősítik az ipar vidéki gazdasági terek differenciálódásában játszott ma is jelentôs szerepét, de még hangsúlyosabban hívják fel a figyelmet a globális termelési hálózatokba kapcsolódás minőségének, a feljebb lépés gazdasági és társadalmi dimenzióinak fontosságára.

Területi Statisztika, 2018, 58(6): 610-637; DOI: 10.15196/TS580604 


\section{A vizsgált nagyvárosok relatív pozíciói}

Relative position of the minor cities examined

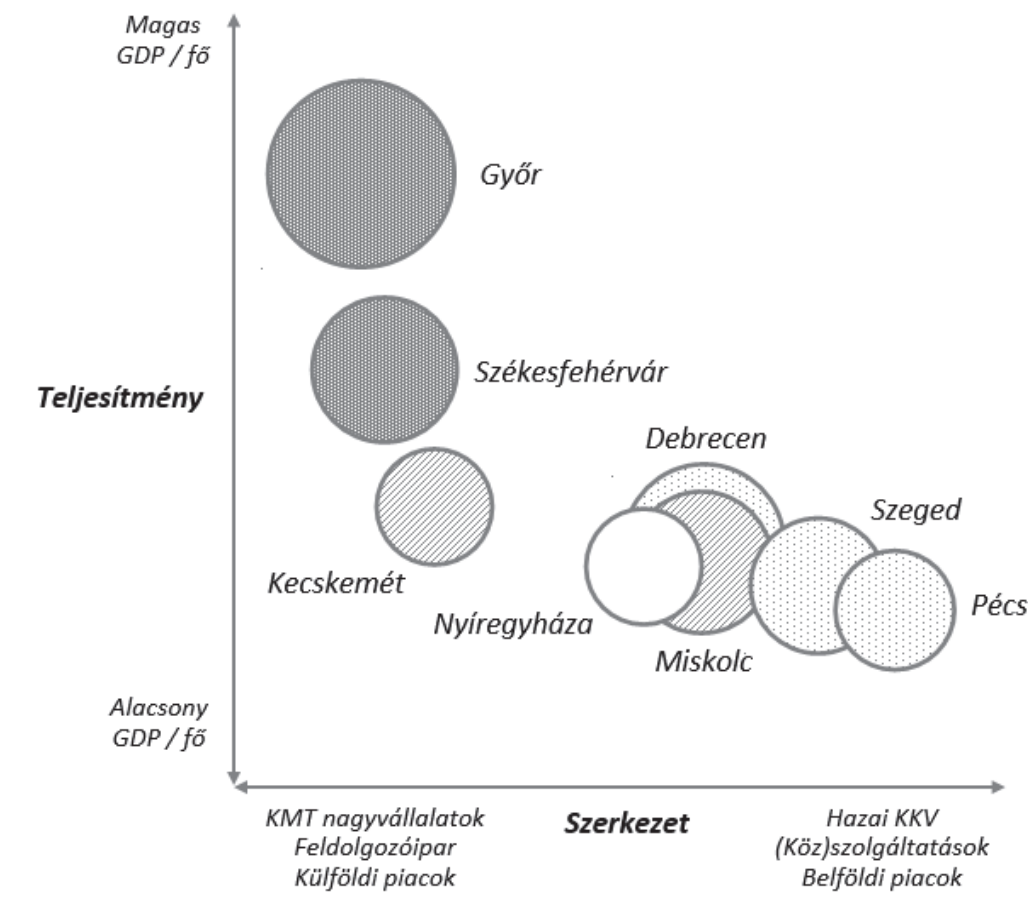

Megjegyzés: Győr, Székesfehérvár: KMT (külföldi működő tőke) dominált feldolgozóipari megye városa; Kecskemét, Miskolc: újraiparosodó megye városa;

Nvíregyháza: rurális jellegủ megye városa;

Debrecen, Pécs, Szeged: tudásközpont megye városa;

(elnevezések Lengyel-Varga 2018 tipizálási rendszere alapján).

A vizsgált nyolc nagyváros karaktere markáns különbségeket mutat a fajlagos gazdasági teljesítménymutatókban, illetve a strukturális jellemzókben. Sajátos csoportot képez a fôvároshoz közelebb lévő, erősen újraiparosodott, külföldi tulajdonú nagyvállalatok (jármű- és elektronikai ipar) által dominált, vállalati mutatóiban erős Győr és Székesfehérvár, illetve az elmúlt évtizedben hasonló fejlődési pályára került, teljesítményének több elemében hozzájuk húzó Kecskemét. E településkörtől markánsan eltér a három népesebb, intézményi-funkcionális szempontból fejlett regionális központ (Pécs, Szeged, Debrecen „tudásközpontok”), melyek pozíciója jobb, ha a helyi székhelyú vállalati szektoron kívüli, jellemzően közszolgáltatáshoz kötődő gazdasági teljesítményeiket is számításba vesszük. Pécs és Szeged - úgy tűnik - kimarad az újraiparosodás folyamatából és előbbi a kultúra, utóbbi a tudomány felé

Területi Statisztika, 2018, 58(6): 610-637; DOI: 10.15196/TS580604 
orientálódik (egyelőre gazdasági potenciált kifejező mutatóikra kevés hatással). Az ipari hátterét részben megórizni, illetve megújítani képes Debrecen adatai - vizsgálatunk eredményei alapján is - a rendszerváltás szerkezeti válságából napjainkra kilábalt Miskolchoz és a megyéjéből szigetszerúen kiemelkedő Nyíregyházához hasonló, „köztes” helyzetre utalnak (6. ábra).

Eredményeink alapján, a hivatkozott (megyei szintü) területi elemzés (LengyelVarga 2018) besorolásától eltér Kecskemét és Debrecen pozíciója, ami egyrészt magyarázható a városok és megyéjük gazdasági jellemzókben mutatkozó különbségeivel, másrészt lehet a két település hosszabb távú „csoportváltó” karakterének kifejezője. A Magyar Nemzeti Bank 2018 szeptemberében kiadott, 2016 óta bejelentett nagyberuházások listáját is tartalmazó inflációs jelentése alapján mindkét város teljesítményében jelentős növekedés várható, mely gazdasági szerkezetük ipar felé tolódásával párosul. Kecskemét a 10 milliárd forintot elérô nagyberuházások összértéke alapján első helyen áll a Mercedes gyárának 2500 új munkahelyet teremtő bővitésével, ez a vizsgált időszakban bejelentett magyarországi nagyberuházások teljes értékének 24\%-a. A legtöbb projekt (BMW, Continental, FAG, Richter Gedeon, Krones, Alföldi Tej) ugyanakkor Debrecenben valósul meg, melyek együttesen a nagyberuházások összértékének 21\%-át képviselik, és közel 2800 új munkahelyet teremtenek. Utóbbi város helyzete nemcsak azért érdekes, mert az újraiparosodás nagyobb hullámai - a korábbiakhoz képest - összetettebb intézményi-funkcionális struktúrával rendelkező regionális központot érnek, hanem azért is, mert az újraiparosodás e nagyságrendje először figyelhető meg a főváros egyórás körzetén kívül. Debrecen és Kecskemét pozíciójának várható változása az itt bemutatott erősorrend- és szerkezeti vizsgálatok ismételt elvégzését teszi szükségessé, egyúttal némi reményt adva arra, hogy az alföldi megyék hazai gazdaságon belüli pozíciója erősödhet.

Nagyvárosaink gazdasági differenciálódása magyarázható a településmérettől függő agglomerációs gazdaságosság, valamint a városhálózat sűrűségéből és összekapcsoltságából levezethető kölcsönzött méret fogalmai által leírt mechanizmusokkal. Egyrészt, nemzetközi léptékben közepes méretűnek számító, ezért kritikus tömegproblémákkal szembesülő nagyvárosainkban is fellelhetők bizonyos, egy-egy gazdasági ág tömörüléséhez köthető marshalli lokalizációs előnyök, melyre bizonyíték lehet az egyes városok stabilnak tűnő, múltban gyökerező ágazati specializációja. Győrben és Székesfehérváron a helyi adottságok stratégiailag összekapcsolódtak (Coe et al. 2004) a betelepülő külföldi múködő tôke igényeivel, így ott dinamikusabb a gazdasági megújulás. Másrészt, a más koncentrációk közelségéből eredő pozitív hatásként értelmezhető kölcsönzött méret kiaknázásának igénye felértékeli nagyvárosaink külső összekapcsoltságát, közlekedési és kommunikációs infrastruktúrájuk minőségét (EC 2016). Eddig elsősorban a Budapest-Bécs közötti térben fekvő, autópálya-hálózatba korán bekapcsolt Győr és Székesfehérvár, valamint - fôvvároshoz legközelebb eső „keleti” nagyvárosként - Kecskemét profitálhatott e tényezőből. Ha a „Budapestországon” kívül található Debrecen fejlődésében bekövetkezik a

Területi Statisztika, 2018, 58(6): 610-637; DOI: 10.15196/TS580604 
vizionált léptékváltás, az - akár a közeli szomszédok (Nyíregyháza, Nagyvárad), akár a várost Európa több jelentős gazdasági csomópontjával összekötő regionális repülőtér magyarázó szerepének felvetésével - jelentős ösztönzést adhat az agglomerációs gazdaságosság és kölcsönzött méret kérdésével összefüggő hazai kutatásoknak is. Hogy az erôviszonyok várható módosulása jelenthet-e hosszabb távon változást Budapest és a vidéki nagyvárosok gazdasági potenciálja között fennálló óriási különbségekben, mérséklődhet-e az ország térszerkezetének egypólusúsága, az ezzel együtt is a jövő kérdése.

\section{Köszönetnyilvánítás}

Molnár Ernő munkáját a Bolyai János Kutatási Ösztöndíj támogatta.

\section{IRODALOM}

Ambrus, Z.-Kissné Majtényi, M.-Kólyáné Sziráki, Á.-Malakucziné PókA, M. (2008): Nagyvárosok összehasonlító vizsgálata Területi Statisz̨tika (48) 2: 136-163.

Aubert, A.-JÓNÁs-BERKI, M.-PIRISI, G.-TRócsánYI, A. (2010): A kultúra és a turizmus szerepe Pécs funkcionális és strukturális átalakulásában Földrajz̨i Közlemények (134) 3: 329-342.

BArrientos, S.-GEREFFI, G.-Rossi, A. (2011): Economic and social upgrading in global production networks: A new paradigm for a changing world International Labour Review 150 (3-4): 319-340. https://doi.org/10.1111/j.1564-913X.2011.00119.x

BARTA, GY. (2005): Nemzetközi funkciók. Munkamegosztás a hét nagyváros között Magyarországon Falu, Város, Régió 12 (3-4): 35-42.

BARTA, GY.-LÓCSEI, H. (2011): The effect of the recent economic crisis on the spatial structure of Hungarian industry Regional Statistics 1 (1): 99-109.

BELusZKY, P.- GYŐRI, R. (2004): Fel is út, le is út... Városaink településhierarchiában elfoglalt pozícióinak változásai a 20. században Tér és Társadalom 18 (1): 1-41.

https://doi.org/10.17649/TET.18.1.929.

BOROS, L. (2009): Szeged belső térfolyamatai az 1950-es évektől napjainkig Földrajzi Közlemények 133 (4): 453-465.

CAmagni, R.-CAPello, R.- CARAgliU, A. (2013): Structural dynamics of second vs. first rank cities: similar laws, different nature. XXXIV Conferenza scientifica annuale AISRe „Crescita economica e reti regionali: nuove industrie e sostenibilità” Palermo, 2-3 Settembre 2013.

Coe, N. M.-Hess, M.-Yeung, H. W.-Dicken, P.- Henderson, J. (2004): „Globalizing” regional development: a global production network perspective Transactions of the Institute of British Geographers 29 (4): 468-484. https://doi.org/10.1111/j.00202754.2004.00142.x

Csomós, GY. (2011): A közép-európai régió nagyvárosainak gazdaságirányító szerepe Tér és Társadalom 25 (3): 129-140. https://doi.org/10.17649/TET.25.3.1872.

Csomós, Gy. (2013): Magyarország gazdasági központjainak pozícióváltozása 1992 és 2011 között Területi Statisztika 53 (6): 529-550.

Területi Statisztika, 2018, 58(6): 610-637; DOI: 10.15196/TS580604 
CsOmós, GY. (2015): The ranking of cities as centres of the Hungarian economy, 1992-2012 Regional Statistics 5 (1): 66-85. https://doi.org/10.15196/RS05104

DÖBRÖNTE, K. (2018): A közép-európai városok pozíciója a magas szintű üzleti szolgáltatók lokációs döntéseiben Területi Statištikea 58 (2): 200-219. https://doi.org/10.15196/TS580204

EGEDY, T. (2012): A gazdasági válság hatása a nagyvárosok versenyképességére Magyarországon Földrajzi Közlemények 136 (4): 420-438.

ENYEDI, Gy. (2000): Globalizáció és a magyar területi fejlődés Tér és Társadalom 14 (1): 1-10. https://doi.org/10.17649/TET.14.1.554

FARAGÓ, L. (2010): Pécs fejlődési pályája - Egy pécsi polgár szemével Területfejlesztés és Innováció 4 (1): 2-14.

FARAGÓ, L.-LuX, G. (2014): Kurrens portéka vagy múzeumi tárgy? Növekedési pólusok és iparági körzetek a fejlesztéspolitikában Tér és Társadalom 28 (2): 11-30. https://doi.org/10.17649/TET.28.2.2614.

Frick, S. A.-RodríGuez-Pose, A. (2017): Big or small cities? On city size and economic growth Papers in Evolutionary Economic Geography. Utrecht University.

GÁL, Z. (2016): Egyetem és a város Educatio 25 (2): 220-233.

GONDA, T.-CSAPÓ, J. (2014): Az Európa kulturális fővárosa cím elnyerésének hatása a kulturális turizmus és a kulturális ipar fejlődésére Maribor, Nagyszeben és Pécs esetében Településföldrajzi Tanulmányok 3 (2): 154-165.

HONVÁRI, J. (SZERK.) (2014): Györ fejlődésének mozgatórugói Universitas-Győr Nonprofit Kft., Győr.

Humphrey, J.-SCHMitz, H. (2002): How does insertion in global value chains affect upgrading in industrial clusters? Regional Studies 36 (9): 1017-1027. https://doi.org/10.1080/0034340022000022198

JózSA, V. (2014): A Robert Bosch csoport miskolci letelepedése és beágyazódásának folyamata Tér és Társadalom 28 (2): 199-213. https://doi.org/10.17649/TET.28.2.2616

JuHÁsz, S.-LENGYEL, B. (2016): Kik formálják a klasztereket? Egy helyi tudáshálózat elemzése Területi Statisztika 56 (1): 46-65. https://doi.org/10.15196/TS560104

KÁDÁR, K.-KOZMA, G. (2011): Az egykori szovjet katonai területek funkcióváltása Debrecenben Tér és Társadalom 25 (2): 164-179.

https://doi.org/10.17649/TET.25.2.1818

KANALAS, I. (2016): Kecskemét város fejlődésének stratégiai irányai Forrás 48 (7-8): 150-168.

KISS, É. (2010): Területi szerkezetváltás a magyar iparban 1989 után Dialóg Campus Kiadó, Budapest, Pécs.

KISS, É. (2011): A válság területi konzekvenciái az iparban Területi Statisz̨tika 51 (2): 161-180.

KIss, J. (1998): Az ágazati gazdaságszerkezet szerepe a regionális differenciálódásban Magyarországon Tér és Társadalom 12 (1-2): 143-170. https://doi.org/10.17649/TET.12.1-2.466

KÓKAI, S. (2004): Nyíregyháza társadalmi-gazdasági fejlődése 1960-tól napjainkig Földrajzi Közlemények 128 (1-4): 113-125.

KovÁcs, Sz.-LuX, G.-PÁGER, B. (2017): A középvállalatok szerepe a feldolgozóiparban: egy magyarországi kutatás első eredményei Területi Statisztika 57 (1): 52-75. https://doi.org/10.15196/TS570103

Területi Statisztika, 2018, 58(6): 610-637; DOI: 10.15196/TS580604 
KovÁcs, Z. (2017): Városok és urbanizációs kihívások Magyarországon Magyar Tudomány 178 (3): 302-310.

KovÁcs, Z.-EGEDY, T.-SZABÓ, B. (2011): A kreatív gazdaság földrajzi jellemzői Magyarországon Tér és Társadalom 25 (1): 42-62. https://doi.org/10.17649/TET.25.1.1772

KozMA, G. (1999): A városmarketing elemeinek alkalmazása Debrecenben a rendszerváltozás után Studia Geographica, 7. Debrecen.

KUKELY, GY. (2006): A nagyvárosok felértékelődése a külföldi múködőtőke - beruházások telephelyválasztásában. Tér és Társadalom 20 (4): 111-125. https://doi.org/10.17649/TET.20.4.1081

KUKELy, GY. (2008): A külföldi müködötöke berubázások hatása az ipar területi folyamataira Magyarországon, különös tekintettel a delokalizációra. Doktori (Ph.D.) értekezés. ELTE, Természettudományi Kar, Földrajz- és Földtudományi Intézet, Budapest.

LADOS, M. (SZERK.) 2014: A gazdaságszerkęzet és vonzáskërzet alakulása. Universitas-Győr Nonprofit Kft., Győr.

LENGYeL, I.-LuKovics, M.-ImREH, Sz. (2018): Tudásalapú fejlesztési koncepció egy kevésbé fejlett régióban: az ELI-ALPS lézeres kutatóközpont Szegeden In: Lengyel, I. (szerk.). Térségek növekedése és fejlödése: egészségipari és tudásalapú fejlesżtési stratégiák pp. 153-173., JATEPress, Szeged.

LENGyel, I.-RECHNiTZER, J. (2000): A városok versenyképességéről In: Horváth, Gy.Rechnitzer, J. (szerk.): Magyarország területi szerkęzete és folyamatai az ezredfordulón pp. 130-152., MTA RKK, Pécs.

LENGYEL, I.-VARGA, A. (2018): A magyar gazdasági növekedés térbeli korlátai - helyzetkép és alapvető dilemmák Közgazdasági Szemle 65 (5): 499-524. https://doi.org/10.18414/KSZ.2018.5.499

LENGyel, I. M.-MolnÁR, E. (2015): The role of path-dependence in the local economic transformation Journal of the Geographical Institute "Jovan Cvijic" 65 (3): 373-390. https://doi.org/10.2298/IJGI1503373L

LŐCSEI, H.-NEMES NAGY, J. (2003): A Balatoni régió gazdasági súlya és belső térszerkezete In: Nemes Nagy, J. (szerk.). Kistérségi mozaik pp. 134-149., Regionális Tudományi Tanulmányok 8. ELTE Regionális Földrajzi Tanszék - MTA-ELTE Regionális Tudományi Kutatócsoport, Budapest.

LuX, G. (2013): Kritikus tömeg alatt: a fejlesztési együttműködés lehetőségei a kisebb nagyvárosokban Tér és Társadalom 27 (4): 52-74. https://doi.org/10.17649/TET.27.4.2512

Lux, G. (2017): Újraiparosodás Közép-Európában Dialóg Campus Kiadó, Budapest, Pécs.

MARSA, A. (2002): Kecskemét, a Dél-Alföld "kistigrise" és a külföldi múködőtőkeberuházások - I-II. rész Külgazdaság (46) 5 / 6: 53-75 / 59-73.

MEIJERS, E. J.-BURGER, M. J. (2017): Stretching the concept of 'borrowed size' Urban Studies 54 (1): 269-291. https://doi.org/10.1177/0042098015597642

Meijers, E. J.-Burger, M. J.-Hoogerbrugge, M. M. (2016): Borrowing Size in Networks of Cities: City Size, Network Connectivity and Metropolitan Functions in Europe Papers in Regional Science 95 (1): 181-198. https://doi.org/10.1111/pirs.12181

MOLNÁR, B. (2004): Székesfehérvár az európai és magyar urbanizációs folyamatokban Földrajzi Értesitö 53 (3-4): 271-292.

Területi Statisztika, 2018, 58(6): 610-637; DOI: 10.15196/TS580604 
MOLNÁR, E. (2013): A közlekedési adottságok szerepe a Hajdú-Bihar megyei ipari parkok fejlődésében In: Kiss, É. (szerk.). A hazai ipari parkok különböző dimenqióban pp. 144-161., Dialóg Campus Kiadó, Budapest, Pécs.

NAGY, E. (2003): Növekedés, differenciálódás és koncentráció: a szolgáltató szektor térszerkezetének változási irányai Magyarországon Falu, Város, Régió 10 (9): 3-9.

NAgY, E.-NAgY, G. (2008): A városok gazdasági potenciálja. A településhálózat fejlesztését célzó politika megalapozása a gazdaság oldaláról. Városok az átalakuló gazdaság térszerkezetben Falu, Város, Régió 15 (3): 32-42.

NAGY, E.-NAGY, G. (2009): Changing spaces of knowledge-based business services in Hungary Hungarian Geographical Bulletin 58 (2): 101-120.

Nemes NAgy, J. (1996): Centrumok és perifériák. a piacgazdasági átmenetben Földrajz̨i Közlemények 120 (1): 31-48.

Nemes Nagy, J. (2004): Új kistérségek, új városok. Új versenyzők? In: Nemes Nagy, J. (szerk.). Térségi és települési növekedési pályák. Magyarországon pp. 5-42., Regionális Tudományi Tanulmányok 9. ELTE Regionális Földrajzi Tanszék - MTA - ELTE Regionális Tudományi Kutatócsoport. Budapest.

PÁLÓCZI G. (2016): Researching commuting to work using the methods of complex network analysis Regional Statistics 6 (1): 3-22. https://doi.org/10.15196/RS06101

PÁTHY, Á. (2017): Types of development paths and the hierarchy of the regional centres of Central and Eastern Europe Regional Statistics 7 (2): 124-147. https://doi.org/10.15196/RS070202

PÉNZES, J. (2014): Periférikus térségek lehatárolása. Dilemmák és lehetóségek Didakt, Debrecen.

PÉNZES, J. (2015): A területi centrum-periféria viszonyok változása az Alföldön In: Tésits, R.- Alpek, B. L. (szerk.): A mi geográfiánk - Tóth József emlékezete pp. 353-366., Publikon Kiadó, Pécs.

PÉnzes, J.-MolnÁr, E.-PÁLóCZI, G. (2015): Local Labour System after the turn of the Millennium in Hungary Regional Statistics 5 (2): 62-81. https://doi.org/10.15196/RS05204

ReChnitzer, J. (2016): A terïleti töke a városfejlódésben - A Györ-kód Dialóg Campus Kiadó, Budapest, Pécs.

RECHNiTZER, J.-CsiZMADiA, Z.-GrosZ, A. (2004): A magyar városhálózat tudásalapú megújító képessége az ezredfordulón Tér és Társadalom 18 (2): 117-156. https://doi.org/10.17649/TET.18.2.949

RECHNITZER, J.-PÁTHY, Á.-BERKES, J. (2014): A magyar városhálózat stabilitása és változása Tér és Társadalom 28 (2): 105-127. https://doi.org/10.17649/TET.28.2.2623

SÜLI-ZAKAR, I.-KOZMA, G.-EKÉNÉ ZAMÁRDI, I.-TEPERICS, K. (2006): A kulturális gazdaság jelentősége Debrecenben In: Kiss, E. É. (szerk.): A népességtöl a természeti eróforrásokig: tisz̧teletkötet Rétvári Lász̧ló 70. születésnapjára pp. 169-188., Nyugatmagyarországi Egyetem Közgazdaságtudományi Kar, Sopron.

SzABÓ, M. (2017): Spatial distribution of the top 500 companies on regional and county levels in Hungary - a repeated analysis. Regional Statistics 7 (2): 148-170. https://doi.org/10.15196/RS070208

SZALAVETZ, A. (2012): A „,feljebb lépési” teljesítmény mérése a globális értékláncokon belül Külgazdaság 56 (3-4): 66-86.

Területi Statisztika, 2018, 58(6): 610-637; DOI: 10.15196/TS580604 
TAYlor, P. J.-Hoyler, M.-SÁnCHEZ-Moral, S. (2013): European Cities in Globalization: A Comparative Analysis based on the Location Strategies of Advanced Producer Services In: Cuadrado-Roura, J. R. (ed): Service Industries and Regions: Growth, Location and Regional Effects pp. 285-304., Springer, Berlin and Heidelberg.

TóTH, G.-NAGY, Z. (2013): Eltérő vagy azonos fejlődési pályák? A hazai nagyvárosok és térségek összehasonlító vizsgálata Területi Statisztika 53 (6): 593-612.

VAS, Zs. (2009): Közelség és regionális klaszterek: a szoftveripar Szegeden Tér és Társadalom 23 (3): 127-145. https://doi.org/10.17649/TET.23.3.1261

VAS, Zs.-LENGYEL, I.-SZAKÁLNÉ KANÓ, I. (2015): Regionális klaszterek és agglomerációs előnyök: feldolgozóipar a magyar városrégiókban Tér és Társadalom 29 (3): 49-72. https://doi.org/10.17649/TET.29.3.2697

\section{INTERNETES HIVATKOZÁSOK}

ESPON (2013): FOCI Future Orientations for CIties 2013. ESPON.

Magyar Nemzeti Bank (2018): Inflációs jelentés 2018 szeptember 2018. Magyar Nemzeti Bank.

EC (2016): The State of European Cities 2016. European Commission, UN-Habitat.

Területi Statisztika, 2018, 58(6): 610-637; DOI: 10.15196/TS580604 